\title{
How the Geomagnetic Field Influences Life on Earth - An Integrated Approach to Geomagnetobiology
}

\author{
Weronika Erdmann ${ }^{1}$ (D) Hanna Kmita ${ }^{2}$ (D) . Jakub Z. Kosicki ${ }^{3}$ (D $\cdot$ Łukasz Kaczmarek $^{1}$ (D)
}

Received: 3 March 2021 / Accepted: 12 June 2021 / Published online: 7 August 2021

(c) The Author(s) 2021

\begin{abstract}
Earth is one of the inner planets of the Solar System, but - unlike the others - it has an oxidising atmosphere, relatively stable temperature, and a constant geomagnetic field (GMF). The GMF does not only protect life on Earth against the solar wind and cosmic rays, but it also shields the atmosphere itself, thus creating relatively stable environmental conditions. What is more, the GMF could have influenced the origins of life: organisms from archaea to plants and animals may have been using the GMF as a source of spatial information since the very beginning. Although the GMF is constant, it does undergo various changes, some of which, e.g. a reversal of the poles, weaken the field significantly or even lead to its short-term disappearance. This may result in considerable climatic changes and an increased frequency of mutations caused by the solar wind and cosmic radiation. This review analyses data on the influence of the GMF on different aspects of life and it also presents current knowledge in the area. In conclusion, the GMF has a positive impact on living organisms, whereas a diminishing or disappearing GMF negatively affects living organisms. The influence of the GMF may also be an important factor determining both survival of terrestrial organisms outside Earth and the emergence of life on other planets.
\end{abstract}

Keywords Geomagnetobiology · Evolution · Astrobiology

\section{Introduction}

Earth is one of the inner planets of the Solar System and like its two closest neighbours, Venus and Mars, it is a rocky planet (Rao 1980). However, unlike Mars and Venus, Earth is habitable, has an oxidising atmosphere with a well-developed ozone layer, and - above all - a unique magnetic field.

Weronika Erdmann

weronika.erdmann@gmail.com

1 Department of Animal Taxonomy and Ecology, Faculty of Biology, Adam Mickiewicz University in Poznań, Uniwersytetu Poznańskiego 6, 61-614 Poznań, Poland

2 Department of Bioenergetics, Faculty of Biology, Adam Mickiewicz University in Poznań, Uniwersytetu Poznańskiego 6, 61-614 Poznań, Poland

3 Department of Avian Biology and Ecology, Faculty of Biology, Adam Mickiewicz University in Poznań, Uniwersytetu Poznańskiego 6, 61-614 Poznań, Poland 
Earth's magnetic field, also called the geomagnetic field (GMF), is a global vector field, which means that in each point of space the magnetic field is defined by a vector of the magnetic field. This vector is represented by coordinates in the Geographic Coordinate System (GCS). In the International System of Units (SI) the intensity of the GMF is measured in tesla units (T), although gauss units $(\mathrm{G})$ are still frequently used. Its strength varies naturally, ranging from approximately 25 to $65 \mu \mathrm{T}(0.25-0.65 \mathrm{G})$ (Finlay et al. 2010).

Although the GMF can be considered as a sum of several different fields, such as a uniform magnetic field, continental magnetic field, anomalous magnetic field, external magnetic field, and a variation field, the main role is played by a uniform magnetic field (Dubrov 1978). The GMF could be also considered as a sum of two components, such as the Internal or the Main Field (generated by geodynamo) (Bullard 1949) and the External Field (generated by interactions between the solar wind and the Earth's ionosphere) (Glassmeier and Vogt 2010). Currently, Earth's magnetic poles are near geographical poles (Clark 1979), however, a long-term drift of geomagnetic poles (World Data Center for Geomagnetism 2012) can be observed. Still, the GMF is considered as a constant magnetic field, which means that it is free from variations with a period of a year or shorter, because its main components, i.e. uniform magnetic field, continental magnetic field, anomalous magnetic field, (Dubrov 1978) are constant. Rapid changes of less than a year (Dubrov 1978) in the GMF occur only in the time-varying component of the GMF of a very low intensity, known as the 'variation field', which is generated by electric current systems in the ionosphere (Dubrov 1978).

According to a dominant hypothesis, Earth did not have a magnetic field in its early days. Originally, weak magnetic fields in our galaxy induced fluid movement in the core of Earth, leading to a relatively quick formation of the field (Clark 1979). Undoubtedly, the Earth's GMF had already existed when life appeared on the planet 3.5-4.3 billion years ago (Tarduno et al. 2010; Gargaud et al. 2012).

Scientists have long been interested in the origins and evolution of life on Earth, and the role the GMF played in the process (Kirschvink et al. 1985). The knowledge of this relationship is very important not only for the understanding of the origins of life on Earth and its further evolution, but also for chances of finding life on other planets and/or moons.

Having searched the phrase 'Geomagnetic field' in scientific browsers, i.e. the SCOPUS and the Web of Science (WoS) (Fig. 1a; SI 1), we found over 21,000 and 19,000 hits, respectively. The oldest paper dates back to the first half of the twentieth century (McNish 1940), a period when the dynamo theory was formulated (McNish 1940). Since then, the interest in this field has been constantly rising. As a result, a growing number of studies and papers have appeared that focus on the GMF as a fundamental environmental drive in the evolution life on Earth.

Apart from the original term 'geomagnetic field', 'geomagnetism' has also been used since 1939 (Fleming 1939). For example, in the SCOPUS the number of hits amounted to over 600 until the end of 1970s, while in the WoS it was a tenth of that number (Fig. 1b; SI 1). Besides, until the end of 2020 there was a large discrepancy between results in these databases with nearly 18,000 hits in the SCOPUS and only a little over 1,000 in the WoS (Fig. 1b; SI 1). Nevertheless, the issue has become increasingly studied over the years.

At first, scientists were mostly interested in the impact of the GMF on animals. The phrases 'Geomagnetic Field' and 'Animals' appeared alongside in papers before 1970 (SCOPUS) or the early 1970s (WoS) (SI 1). Soon, scientists took interest in plants, and first studies on the impact of Earth's magnetic field on plants appeared in the SCOPUS between 1970 and 1980, and a decade later in 1990, according to the WoS (SI 1). At the same time, the term 'Magnetoreception' was coined, and 15 hits can be spotted before 

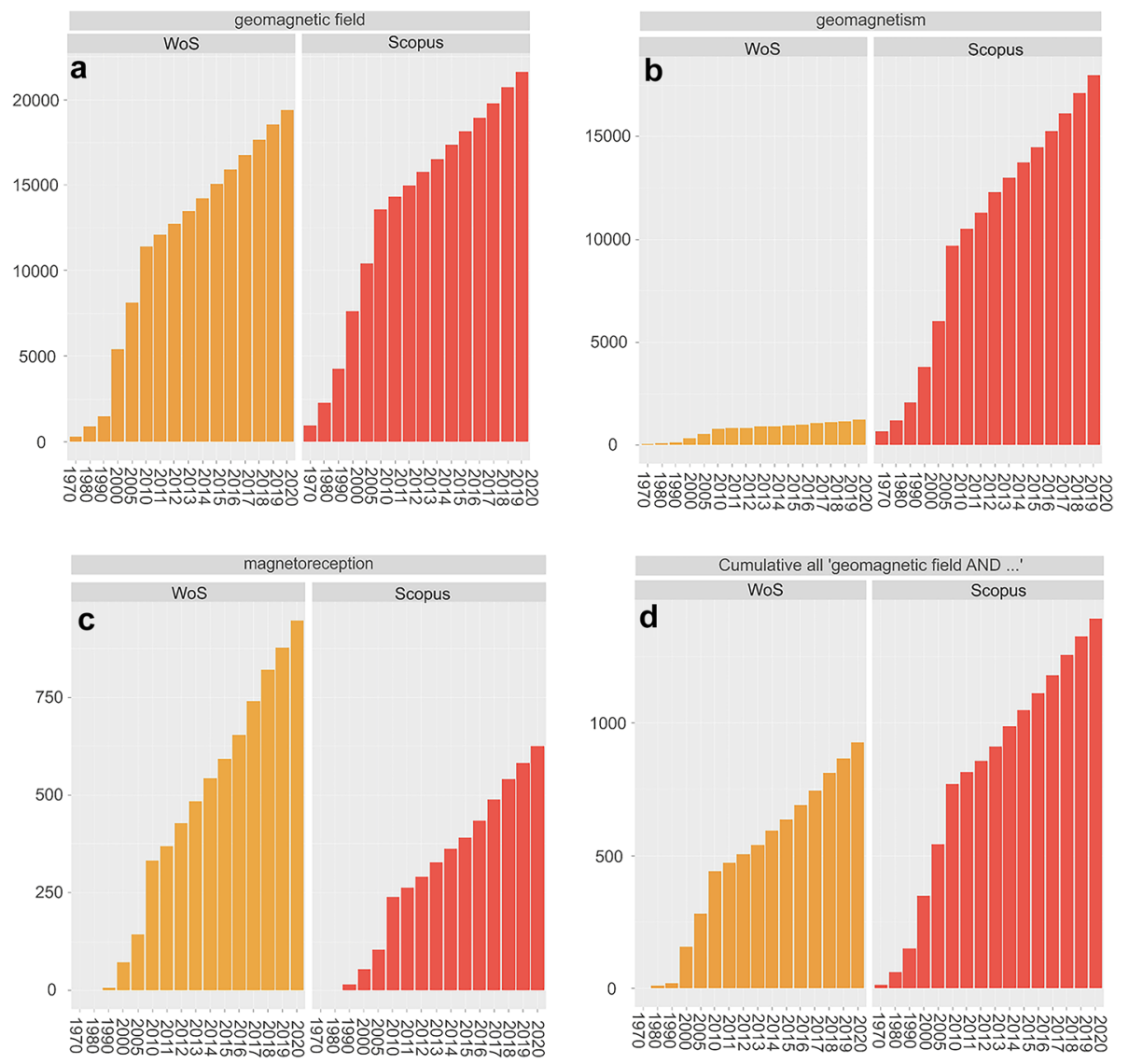

Fig. 1 Changes in interest in GMF-related topics expressed as changes in the number of publications, in subsequent time periods (Scopus/WoS) until the end of 2020 (data obtained 06.05.2021) for keywords and phrases, a 'Geomagnetic Field', b 'Geomagnetism', c 'Magnetoreception' and d Cumulative results for all phrases 'Geomagnetic Field AND

1990 (SCOPUS), and seven between 1980-1990 (WoS) (Fig. 1c; SI 1). Apart from studies on the GMF's impact on animals, cells were also taken into account with the first paper before 1970, six others that included 'Geomagnetic field' and 'cells' (SCOPUS) or six further papers in the following decade (WoS) (SI 1).

Subsequently, further questions were raised, for example how the geomagnetic reversal contributed to mass extinctions. In fact, this issue has been rarely discussed: the first paper appeared before 1980 (SCOPUS) or in the early 1990s (WoS) (SI 1). At present, only 27 papers are recorded in the WoS and 26 in the SCOPUS (SI 1). Finally, the term 'magnetofossils' occasionally appears in both databases in the context of the geomagnetic field, it is one hit in SCOPUS and two in WoS until the end of 2020 (SI 1).

Our analyses show that the GMF and its impact on life on Earth raised interest in the late 1930s, and since then it has been increasing (SI 1). This is visible in results from both SCOPUS and WoS for all the phrases 'Geomagnetic Field' (Fig. 1a), 'Geomagnetism' (Fig. 1b), 'Magnetoreception' (Fig. 1c). and for cumulative results for phrases 'Geomagnetic Field AND ...' (Fig. 1d). Nevertheless, there is no comprehensive review of the 
knowledge on the topic. Many researchers focus on a small fraction of this broad research field, testing only the direct or indirect effects of the GMF. So far, the broadest review in the field of geomagnetobiology has been Dubrov's work 'The geomagnetic field and life: Geomagnetobiology', However, it was published in 1978, which makes it outdated in many aspects. Similarly, 'Magnetite Biomineralisation and Magnetoreception in Organisms: A New Biomagnetism' published in 1985 (Kirschvink et al. 1985) provides an in-depth overview of the state of the knowledge in magnetosome-based magnetoreception and the magnetite biomineralisation process itself, Still, it is also an old book and there is a shortage of discoveries from last thirty-five years. Another problem concerns review articles from that time, such as 'Bird orientation and the geomagnetic field: A review.' (Ossenkopp and Barbeito 1978), 'Biophysics of geomagnetic field detection' (Kalmijn 1981) or 'How the geomagnetic field vector reverses polarity' (Prévot et al. 1985). First of all, they are outdated in some respect, but they are also more specialised and present knowledge in very narrow topics. Nonetheless, older books and articles can provide valuable information. We often find references to even older basic research which laid the foundations for modern geomagnetobiology or operated in such unique fields that they have never been continued and their results are still valid today. In modern literature we do not find any paper as thorough as Dubrov's 'Geomagnetobiology'. More recent review articles like 'Magnetotactic bacteria, magnetosomes and their application' (Yan et al. 2012) or 'Biological effects of the hypomagnetic field: An analytical review of experiments and theories' (Binhi and Prato 2017) provide more current information, but its form is much more scattered.

Therefore, the main aim of our paper is to present a comprehensive review focused on the impact of the GMF on the origins and evolution of life on Earth, as well as, the influence of the GMF on living organisms at different levels of biological organisation, including the viability of organisms, genetic stability, modulation of gene expression and behaviour. We attempt answer the question: How broad and multi-level is the influence of GMF on living organisms? Such a review should be highly interesting and useful not only for astrobiologists, but also for ecologists, microbiologists, zoologists and botanists.

\section{Survey Methodology}

The analysis of changes in the number of papers on GMF-related topics in the WoS and SCOPUS helped us to determine the degree of interest in the topic. However, we did not limit ourselves just to these two databases, but considered many other publications on the GMF and its impact on the origins and evolution of Earth's biosphere. We also referred to the PubMed and Google Scholar. The search strategy included keywords and phrases, such as geomagnetic field, geomagnetism, magnetoreception, hypomagnetic, geomagnetic field AND life on Earth, geomagnetic field AND evolution of life, geomagnetic field AND cells, geomagnetic field AND animals, geomagnetic field AND plants, geomagnetic field AND microfossils, geomagnetic field AND mass extinction. Finally, we considered such books as "The geomagnetic field and life: Geomagnetobiology" by Dubrov (1978), "Young Sun, Early Earth and the Origins of Life" by Gargaud et al. (2012), and online sources of the World Data Centre for Geomagnetism.

Our study focused on papers published between 1960 and 2020, two papers from the first half of 2021, and historical articles and books published between 1953 and 1959.

In our review, we cite in total 165 papers and 8 books. Most papers deal with narrow subject areas concerning one particular group of organisms, e.g. "Magnetoreception 
in plants" (Galland and Pazur 2005) and "Magnetic orientation in birds" (Wiltschko and Wiltschko 2005) or on specific topics like "Biological effects of the hypomagnetic field: An analytical review of experiments and theories" (Binhi and Prato 2017) and "Biological effects due to weak magnetic field on plants" (Belyavskaya 2004).

\section{The Geomagnetic Field and the Origins of Life on Earth}

The geomagnetic field is thought not only to protect life on Earth, but it also may have contributed to its origins, both directly and indirectly. Its indirect role is associated with the stabilising influence on the environment in which life was developing. This includes: protecting the atmosphere and thus maintaining relatively stable environmental parameters, e.g. reduced temperature variation and water in the liquid state, and later the oxidising atmosphere and the ozone layer.

The GMF protects Earth against the solar wind that constantly blows towards it. The solar wind is mainly a stream of ionised hydrogen atoms, protons, and electrons emitted by the Sun (Geiss et al. 1995; Galvin et al. 1996). If it was not for the GMF, the energy carried by wind particles would be transferred directly to the particles of the atmosphere, giving them additional velocity in the anti-sunward direction. As a result, they would be able to overcome Earth's gravity and escape into the interplanetary space, thus depriving Earth of a significant portion of its atmosphere. A similar process may have determined the atmospheres of Venus and Mars. Chemical signatures in these planets' atmospheres imply that at some point they had had atmospheres similar to Earth's, but they changed when lighter elements from their atmospheres (i.e. hydrogen and oxygen) had been lost, probably partially due to the solar wind and the lack of stable, dipole magnetic field similar to the GMF (Luhmann and Bauer 1992; Svedhem et al. 2007; Futaana et al. 2008; Lammer et al. 2018). Dense and rich 'greenhouse gases' in Venus's atmosphere are believed to have lost their lighter elements due to the solar wind (Lammer et al. 2006). Although it is only a speculation, without the GMF, oxygen, which is a gas significantly lighter than carbon dioxide, hydrogen sulphide or other gases in Earth's early atmosphere, would probably be easily blown away by the solar wind as soon as it appeared in the atmosphere. What is more, apart from oxygen, other lighter gases, such as hydrogen and nitrogen, would escape into the space faster than they could be produced by chemical reactions on Earth and in its atmosphere. Only heavier gases, i.e. carbon and sulphur oxides, would be able to stay close to Earth's surface. As a result, Earth's atmosphere would resemble that of Venus (Krasnopolsky and Parshev 1981; Lammer et al. 2006, 2018; Svedhem et al. 2007).

As far as Mars is concerned, its magnetic field is weaker than Earth's, and it exists solely due to the magnetisation of the surface rocks. In fact, it is not a planetary field and as such it lacks a dipole structure which would protect Mars's atmosphere from being blown away. Besides, the smaller mass of the red planet let the solar wind tear the atmosphere easily away, which in turn resulted in the disappearance of surface water bodies. So, had it not been for the protective influence of the GMF, Earth's oxidising atmosphere could not have emerged and persisted. The examples of Venus and Mars show what happens to the atmospheres of planets which did not develop their inner magnetic fields or lost them earlier on.

Moreover, if Earth failed to have the GMF, solar wind particles that reach the atmosphere would react with atmospheric gases, such as molecular (diatomic) nitrogen $\left(\mathrm{N}_{2}\right)$ and oxygen $\left(\mathrm{O}_{2}\right)$, and thus result in the formation of nitrogen oxide (NO), which would then react with ozone $\left(\mathrm{O}_{3}\right)$ (McElroy and McConnell 1971; Revell et al. 2012; Michalski et al. 
2014). The product of the reaction, nitrogen dioxide $\left(\mathrm{NO}_{2}\right)$, reacts with free radicals of oxygen and forms NO and diatomic oxygen. Eventually, as a result of the decomposition of a single ozone molecule bonded with a single free oxygen atom, two diatomic molecules of oxygen are formed (McElroy and McConnell 1971; Revell et al. 2012; Michalski et al. 2014). In the atmosphere protected by the GMF these reactions also take place, but on a much smaller scale. Most of solar wind particles are deflected from the magnetosphere, and only a small fraction of these highly energetic particles occasionally reaches the atmosphere, igniting the process (Rao 1980). If the GMF was absent, this chain of reactions would continue until the ozone layer was completely destroyed and life with the aerobic metabolism would have no chances to develop (Rao 1980).

The absence of the GMF causes frequent climatic changes that impose severe weather instability. Such a situation happens when there is no GMF and cosmic rays reach Earth. Like the solar wind, cosmic rays consist of high energy particles, consisting of $89 \%$ protons, $10 \% \alpha$-particles (helium nuclei), and 1\% of other heavy particles (Mewaldt 1996), coming from beyond the Solar System. Among the greatest effects of cosmic rays on the atmosphere there is an increase of ionisation of air particles. The ionisation of lower layers of the atmosphere affects a vertical flow of currents between cloud layers and their electrical potential. This phenomenon results in the formation of ice structures in clouds. Therefore, an increased amount of cosmic rays decreases the amount of solar energy reaching Earth's surface, leading to significant climate cooling. However, the rays are attenuated by magnetic fields of the Sun and Earth, then by Earth's atmosphere, rarely reaching the surface of Earth.

Apart from the above indirect contribution to the origins of life on Earth, the GMF could have also had a direct influence, because the GMF controls the access of cosmic rays and solar wind particles. Both are suspected to be possible energy sources needed for the abiotic formation of biologically significant molecules, and thus indirectly responsible for the initiation of prebiotic evolution (Miller and Urey 1959). In that case, the existence, quality, and strength of the GMF had a prevailing influence on the origins of life on Earth.

\section{The Impact of Earth's Geomagnetic Field on Living Organisms}

From the very beginning of their existence, living organisms functioned in the presence of the GMF (Belyavskaya 2004; Borlina et al. 2020) and they need its presence to function properly (Dubrov 1978; Erdmann et al. 2017) on all levels of biological organisation, i.e. cells, tissues, organs and whole organisms.

The GMF, like any other magnetic field, is able to influence, not only ferromagnetic materials like iron, or nickel, but also paramagnets like oxygen, sodium, and diamagnets like zinc, magnesium, copper, phosphorus, water, DNA, many proteins, and even water molecules (Janicki 2008), which are all important for the regulation of cellular processes. Available data including the impact of the GMF's absence, known as hypomagnetic conditions, indicate that the GMF influences: (1) water properties (Janicki 2008); (2) simple and facilitated ion diffusion across membranes (Mika 1996; Zaguła et al. 2011); (3) chromatin condensation (Belyaev et al. 1997); (4) DNA replication (Liboff 1984); (5) gene expression (Blank and Goodman 1997; Mo et al. 2014a); (6) cell cycle (Mo et al. 2013; Surma et al. 2014; Bertea et al. 2015); (7) enzymes activity (Nossol et al. 1993; Zhang et al. 2017) as well as the activity of non-enzymatic proteins including haemoglobin (Janicki 2008) and calmodulin (Markov and Pilla 1994, 1997); (8) the functioning of mitochondria (Fu et al. 
2016); (8) cytoskeleton and cell morphology, adhesion, proliferation and migration (Mo et al. 2014b, 2016; Fu et al. 2016), and (9) cell differentiation to, for example, osteoblasts and muscle cells (Surma et al. 2014; Zhang et al. 2014).

The GMF is also important for the functioning of multicellular organism (Fesenko et al. 2010; Mo 2012; Bertea et al. 2015). For instance, cardiovascular and nervous systems have been proven to be most sensitive to changes in the magnetic field. This sensitivity of the cardiovascular system can be explained mainly by the presence of haemoglobin which contains large amounts of iron ions (Janicki 2008). An analysis of medical records indicates that geomagnetic storms, i.e. disturbances in Earth's magnetosphere caused by bursts of radiation and charged particles emitted from the Sun during coronal mass ejection (Andre et al. 1998), may contribute to the myocardial infarction development, although the underlying mechanism may differ for mid- and high latitudes (Samsonov et al. 1960).

First studies on magnetoreception in plants were conducted as early as the mid-twentieth century, however, little is known about their magnetoreception and sensitivity to the GMF when compared to animals and bacteria. Magnetised water facilitates plant growth, increases fertility, and yields a better harvest (Fernandez et al. 1996; Teixeira da Silva and Dobránszki 2014; Abedinpour and Rohani 2017). Studies on the effects of constant and variable magnetic fields on various species of plants, including fruit trees and shrubs, show that seeds germinate faster under the operating field. The GMF also facilitates differentiation of tissues and organs in young plants which leads to an overall faster growth (Rochalska 2007). It has been also demonstrated that even slight changes in the GMF, caused by a modulation of the amount of solar radiation that reaches Earth's surface, may influence the condition of plants. Numerous studies show that magnetic storms have a negative impact on plants as they may lead to anomalies in nucleus and chromosomes, e.g. widespread emergence of cells with polyploid nuclei or the so-called huge nuclei as well as polynucleated cells (Nanush'yan and Murashev 2003). Furthermore, like in animal cells, by modulating ion channels the magnetic field affects the transport of chemical substances between cells as well as the activity of enzymes and the frequency of cell division (Galland and Pazur 2005).

\section{Studies on Life in Hypomagnetic Conditions}

The absence or significant weakening of the GMF is called hypomagnetic conditions/ hypomagnetic field (HMF) or a Super Weak Magnetic Field (SWMF), however, the terms are not interchangeable. Much research on the effects of hypomagnetic conditions on living organisms was performed in the USA and the former USSR in 1960s and 1970s (Dubrov 1978), and since the early 2000s in other countries, including China, Canada, Japan, Italy, and Romania (Binhi and Prato 2017). Most of the recent studies were summarised and reviewed by Binhi and Prato (2017). The authors showed that a vast majority of studies conducted in hypomagnetic conditions on all sorts of organisms (bacteria, plants, and animals, both vertebrates and invertebrates) demonstrated visible biological effects of hypomagnetic conditions. Their work also implied that those effects were in fact related directly to nonspecific magnetoreception (Binhi and Prato 2017). However, the results of those studies remain ambiguous in some respect. On the one hand, some bacteria species were negatively affected. For example, when colonies of Staphylococcus aureus Rosenbach, 1884 were cultured in hypomagnetic conditions, their colony size and number decreased. Other bacteria cultured in hypomagnetic conditions suffered phenotypic changes of shape and size (e.g. Azotobacter sp.) accompanied by considerable changes in metabolism (e.g. some Escherichia coli Migula, 1895 strains which lost their ability to ferment maltose). On 
the other hand, the growth of E. coli was more rapid in hypomagnetic conditions than in typical magnetic conditions (Dubrov 1978). Besides, Shigella sonnei Weldin, 1927 and Staphylococcus, Salmonella, Klebsiella, Escherichia species developed antibiotic resistance much faster in hypomagnetic conditions (Dubrov 1978). All in all, it cannot be unequivocally determined if such changes are clearly negative or positive, but definitely they are a reaction to hypomagnetic conditions.

Furthermore, the absence of GMF or weak GMF induces severe dysfunctions in animals, including humans. Research conducted by NASA on mice showed decreased enzyme activity in cells obtained from mice kept in hypomagnetic conditions (Conley 1970). Even earlier before that discovery, there had been speculations that a long-term absence of the magnetic field could cause a serious change in their behaviour (cannibalism) and shorten their lifespan as well as bring about other physiological (infertility) and histological (diffuse tissue hyperplasia) dysfunctions (Dyke 1965; Conley 1969). Further studies also revealed that hypomagnetic conditions could inhibit early embryogenesis (Osipenko et al. 2008a, 2008b) and reproduction capacity (Fesenko et al. 2010), impair learning abilities and memory of adult male mice (Wang et al. 2003), and even inhibit stress-induced analgesia in male mice (Seppia et al. 2000; Prato et al. 2005). Other experiments demonstrated that even a short stay of living organisms in hypomagnetic conditions led to noticeable changes in enzymatic reactions and cell divisions of fibroblasts (Sosunov et al. 1972) as well as animal behaviour, i.e. caused an increase in anxiety among the tested male mice (Ding et al. 2019). Studies on rats indicated that hairs of animals shielded from the GMF contained lower levels of certain elements, such as iron, manganese, copper, and chromium, than hairs of animals not shielded from the GMF (Tombarkiewicz 2008). Finally, an exposure of multiple generations to the hypomagnetic conditions resulted in amnesia of Drosophila (Sophophora) melanogaster Meigen, 1830 (Zhang et al. 2004), whereas chickens needed additional noradrenaline for memory consolidation (Xiao et al. 2009). Even anhydrobiotic abilities of tardigrades were inhibited due to a partial isolation from the GMF (Erdmann et al. 2017). In summary, tardigrades manifested increased mortality after exposure to hypomagnetic conditions (Erdmann et al. 2017, 2021).

The first studies on the influence of hypomagnetic conditions on humans were conducted in the 1960s and concerned the health of astronauts in hypomagnetic conditions in the outer space (Becker 1963; Beischer and Miller 1964; Dubrov 1978). These studies showed changes in calcium homeostasis and circadian rhythms as well as a reduced number of erythrocytes. Subsequent tests revealed that a long-term absence of the magnetic field induced sleep disturbance (Dubrov 1978), thus supporting a hypothesis on the negative impact of the GMF on human health. Other studies specifically targeted to estimate the impact of hypomagnetic conditions on human health showed that a three-day isolation from the magnetic field resulted in decreased metabolism, gastrointestinal diseases and a decrease in the number of leukocytes in blood (Dubrov 1978; Janicki 2008). What is more, such functions of the human brain as learning and memorising were also affected (Binhi and Sarimov 2009, 2013).

Apart from the influence on animal and human cells and tissues, hypomagnetic conditions have a negative influence on the development of plants. For example, hypomagnetic conditions causes characteristic changes in the root meristem in pea (Pisum sativum Linnaeus, 1753), common flax (Linum usitatissimum Linnaeus, 1753) and lentils (Lens culinaris Medikus, 1787). These changes included a partial reduction of the meristem, disruption of protein synthesis and accumulation of lipids as well as a reduction of the organelle's growth, the amount of phytoferritin in plastids and crista in mitochondria (Belyavskaya 2001; Galland and Pazur 2005). All of these changes were accompanied by a more rapid increase of the epicotyl (Negishi et al. 
1999). However, it turned out that not all plants reacted in the same extent to a weakened magnetic field. For instance, soya grown in magnetic conditions typical for Mars did not display any changes in water absorption or germination of seeds (Mo et al. 2011). Moreover, seed germination rate of other plants, e.g. French marigold (Tagetes patula Linnaeus, 1753), pot marigold (Calendula officinalis Linnaeus, 1753), rye (Secale cereale Linnaeus, 1753) and alfalfa (Medicago sativa Linnaeus, 1753) was the same in hypomagnetic conditions (near zero T) as in the normal GMF (Teixeira da Silva and Dobránszki 2016). On the other hand, seed germination rates of other higher plants, e.g. cabbage (Brassica oleracea Linnaeus, 1753), was decreased and seedlings development retarded when exposed to a magnetic field in the range of $100 \mathrm{nT}$ to $0.5 \mathrm{mT}$ (Teixeira da Silva and Dobránszki 2016; Tsetlin et al. 2016). Lastly, there are hardly any studies on the effect of hypomagnetic conditions on fungi and protists (Pazur et al. 2007). One of the few such studies on lower fungi (Aspergillus and Penicillium) showed no significant changes in their multiplication (Dubrov 1978).

In conclusion, there is no doubt that the HMF has an effect on living organisms, however, no noticeable connection between the magnitude of this effect and physical conditions (field magnitude, magnetic field inhomogeneity, type and duration of exposure) has been found (Binhi and Prato 2017).

\section{Magnetotaxis and Magnetonavigation}

Living organisms have many different types of senses depending on stimuli and sources of information. Yet, there are two types of signals that are available in the same extent throughout the globe, i.e. gravity and the GMF. Both are very good sources of information, accessible everywhere, independent from light availability (at night, in oceans depths, underground) or weather conditions. The magnetic field freely penetrates internal organs so an organism's magnetic sense does not require any external sensory organs. Moreover, the GMF sensors can be located in any part of the cell/body, because magnetic energy differs from other energy forms (except gravity) that penetrate tissues only to a specific depth (Mika 1996).

\section{Magnetoreception}

Even simple organisms, for example bacteria Magnetospirillum sp. (Kirschvink et al. 1985), Magnetovibrio sp., and Magnetococcus sp. (Yan et al. 2012), and some archaea (Gorobets et al. 2017) can navigate in the magnetic field, an ability known as magnetotaxis (Kirschvink et al. 1985). Bacteria were first described in 1975 to be capable of magnetotaxis, owing to their iron-rich intracellular inclusions (Frankel et al. 1979; Kirschvink et al. 1985). Intracellular inclusions, called magnetosomes, contain magnetite crystals $\left(\mathrm{Fe}_{3} \mathrm{O}_{4}\right)$, and to a lesser extent greigite crystals $\left(\mathrm{Fe}_{3} \mathrm{~S}_{4}\right)$ (Posfai and DuninBorkowski 2006; Posfai and Dunin-Borkowski 2009). The greigite-based magnetosomes were reported only in magnetotactic bacteria from anaerobic, brackish and marine aquatic habitats containing significant amounts of $\mathrm{H}_{2} \mathrm{~S}$ (Pósfai et al. 1998). Both types of crystals have a similar size range from 30 to $120 \mathrm{~nm}$ (mostly from 60 to $90 \mathrm{~nm}$ ), they usually have an elongated shape and contain a single magnetic domain (Pósfai et al. 1998; Posfai and Dunin-Borkowski 2009).

The direction of magnetisation of individual crystals in magnetosomes is defined by the grain size, shape and crystallographic layout. When crystals form a complex system, the 
strength and direction of their magnetisation is also affected by the neighbouring crystals (Bazylinski and Frankel 2004). It has been observed that bacterial cells closely monitor the layout of crystals in the chain (Simpson et al. 2005). A magnetosome formation process is very complex: it comprises a formation of vesicles, transport of iron, nucleation, growth of magnetite crystals, and finally magnetite crystals connecting into chains (Wang and Liang 2009; Posfai and Dunin-Borkowski 2006). It also involves many proteins which control the process of crystals' nucleation (i.e. MamG, MamF, MamD and MamC proteins) and maintain the correct orientation and function of magnetosomes (MamK and MamJ) (Wang and Liang 2009). In addition, magnetite crystal chains may be embedded in the protein core and surrounded by a phospholipid bilayer, e.g. in bacteria Magnetospirillum magnetotacticum Maratea and Blakemore (1981) and M. gryphiswaldense Schleifer et al. (1991) (Watanabe et al. 2009). The protein core is formed by cytoskeleton proteins similar to tubulin (Watanabe et al. 2009). There is also a ftsZ-like protein which exhibits high similarities to proteins of several other non-magnetotactic bacterial and Archaean species, i.e., E. coli, Bacillus subtilis (Ehrenberg, 1835), B. anthracis Cohn, 1872 and Pyrococcus abyssi Erauso et al., 1993, although it exists in this form only in Magnetospirillum strains (Ding et al. 2010). Its exact role is unknown, however, studies showed that disturbances in the formation of magnetosomes were noted in bacteria with mutations in the Fts- $Z$ encoding gene. In this case magnetosomes contained mainly superparamagnetic crystals and had poorly defined morphology (Ding et al. 2010).

There are two different ways which enable magnetotactic bacteria to able detect the magnetic field: axial magnetoreception and polar magnetoreception. For example, the M. magnetotacticum AMB-1 strain shows axial magnetoreception, which means that it passively orientates itself on the magnetic field and may actively move along the lines of force of the magnetic field in both directions from the magnetic pole to the magnetic equator although without any preference towards the magnetic north or south. Conversely, the Magnetococcus sp. MO-1 strain displays polar magnetoreception, so it moves parallel to the lines of the field (to the north magnetic pole, i.e. to south) or antiparallel (going up to the south magnetic pole, i.e. to north), thereby showing preference towards polarity (Lefevre et al. 2009). A single cell equipped with one or more magnetosomes can be regarded as a magnetic dipole, akin to a compass needle with a magnetic moment. The GMF acting on such a dipole generates a torque. As long as the magnetic energy of such a cell is at least ten times larger than its thermal energy, the cell will be directed according to the external magnetic field, which is sufficient for effective navigation in Earth's magnetic field (Bazylinski and Frankel 2004).

Magnetosomes were also found in some single-cell eukaryotes, such as Phytoflagellata and Anisonema (Euglenophyceae). Their cells contain thousands of magnetite crystals, which are very similar to those in magnetotactic bacteria. However, the origin of these magnetosome-like structures is still unknown. It is presumed that some protists are able to perform biomineralisation of endogenous magnetic particles. On the other hand, several observations indicate that some of them do not have this ability and absorb crystals from magnetotactic bacteria which they consume (Torres de Araujo et al. 1986; Bazylinski et al. 2000; Galland and Pazur 2005).

Magnetofossils, i.e. magnetite nanocrystals of organic origins, are found in rocks of various ages. Presumably, the oldest fossils of this type come from layers formed 2.8 billion years ago (Kopp and Kirschvink 2008). Their shape, size and morphology resemble bacterial magnetosomes (Gehring et al. 2011; Chang et al. 2012). The fact that these advanced magnetically sensitive structures are present both in present-day and prehistoric bacteria may indicate that magnetoreception is indeed a very early adaptation. 
The first animals found to have the ability of magnetonavigation were birds, i.e. the European robin (Erithacus rubecula (Linnaeus, 1758)) (Wiltschko and Merkel 1966). Since then, this ability has been confirmed to be present in Platyhelminthes, molluscs, crustaceans, insects and all groups of vertebrates (Wiltschko and Wiltschko 2005; Johnsen and Lohmann 2008; Wajnberg et al. 2010; Ernst and Lohmann 2016; Mouritsen 2018; Yosef et al. 2020). In fact, ecological and behavioural aspects of the use of the magnetic field as a source of information have been studied fairly well. Two mechanisms have been described that can help to explain magnetoreception in animals, i.e. the Magnetite-Based Mechanism (MBM) and the Radical Pair Mechanism (RPM).

The MBM is based on magnetite lumps (Malkemper et al. 2016) and it is very similar to magnetosomes found in bacteria. Various structures can play a role of the MBM detector, from magnetite crystals with a single magnetic domain or multidomain crystals to small crystals with superparamagnetic properties. Single-magnetic domain crystals were found, for example in honey bees (Apis mellifera Linnaeus, 1758) (Wajnberg et al. 2010), chitons (Lowenstamm 1962) and Osteichthyes (Wiltschko and Wiltschko 2006). In cetaceans, apart from single-domain crystals, multidomain crystals were also found (Posfai and Dunin-Borkowski 2009). Tiny crystals with superparamagnetic properties have been observed in nematodes, termites, doves, cetaceans and humans (Kirschvink et al. 1992; Cranfield et al. 2004; Posfai and Dunin-Borkowski 2009). Like in the case of bacteria, magnetite is not the only mineral used in animal magnetoreception, because maghemite $\left(\gamma-\mathrm{Fe}_{2} \mathrm{O}_{3}\right)$ crystals were found in homing pigeons and even humans (Frankel et al. 1979). Moreover, also particles of hematite $\left(\mathrm{Fe}_{2} \mathrm{O}_{3}\right)$ were found in humans, however their function remains unknown (Posfai and Dunin-Borkowski 2006).

Posfai and Dunin-Borkowski (2009) suggested that the magnetoreception system of animals resembled chains of single-magnetic domain crystals recognised in bacteria. According to these authors, the magnetic field opens ion channels by deflection of the chains, thus leading to depolarisation of the cellular membrane and transmission of signals to the brain (Walker et al. 2002). However, other authors claim that magnetoreception is possible due to a system of superparamagnetic crystals with dimensions of 2-5 $\mathrm{nm}$ that do not have a permanent magnetic moment (Davila et al. 2003). These crystals are located in vesicles which change their shape in the presence of a constant magnetic field. Due to such deformation, the vesicles attract or repel each other, leading to a deformation of the membrane to which they are attached. So, it causes an opening of ion channels transmit signals to the central nervous system (Davila et al. 2003).

The RPM appears to be evolutionarily younger than the MBM (Malkemper et al. 2016). It is responsible for a more advanced system of magnetoreception, which enables animals to determine the direction and position of the poles as well as construct a magnetic map in their memory. This mechanism was taken into consideration when it turned out that birds' spatial orientation was impaired when they had one eye covered (especially the right one). Accordingly, it was concluded that the location of the magnetic sense of those animals may be associated with the structure of their eyes (Wiltschko and Wiltschko 2006). Studies from the 1970s and 1980s addressed a hypothesis formulated by Schulten et al. (1978) that assumed that in some organisms, including birds, there must be a chemical compound that reacted both to light and the magnetic field (Schulten and Windemuth 1986). Further research confirmed that cryptochromes, special pigments located in the retina, were responsible for that process (Ritz et al. 2000; Hand 2016; Pinzon-Rodriguez and Muheim 2017). These pigments are common, as Schulten et al. (1978) suspected, in the eyes of many animal species, including humans (Foley et al. 2010). 
Cryptochromes are flavoproteins containing flavin adenine dinucleotide (FAD) They are members of the same family of proteins as photolyases (Hore and Mouritsen 2016). Due to a reaction triggered by green, blue or UV light, cryptochromes absorb a quantum of light, and a pair of free radicals is formed, comprising FAD and one of the protein amino acids (Biskup et al. 2009; Zhang et al. 2015). Then, a conversion between singlet and triplet states occurs and this process is modulated by the magnetic field. The direction of the field's line of induction relative to the position of molecules conditions the parallel orientation of spins for the triplet state and antiparallel for the singlet state. Thus, a formed pair of radicals with a given spin participates in a reaction whose final product is dependent on the spin direction (Wiltschko and Wiltschko 2006). In the case of animals having cryptochromes in their eyes, it may be concluded that the role of the GMF is visible. It is assumed that radical pair singlet and triplet states influence a transfer of stimuli from the eye to the central nervous system and/or these products modify the sensitivity of light-sensitive receptors. Consequently, information reaching the brain is distorted, and it may cause changes in the brightness of a given location depending on the position of the animal's eyes relative to the lines of the GMF (Pinzon-Rodriguez and Muheim 2017; Ritz et al. 2002; Juutilainen et al. 2018).

Animals use their senses like a compass to detect the GMF axis and determine directions. Research show that there are two types of the magnetic compass, i.e. an inclination compass and a polar compass (Wiltschko and Wiltschko 2006). They detect various properties of the GMF and follow different magnetoreception mechanisms (Wiltschko and Wiltschko 2005; Wajnberg et al. 2010). The inclination compass is sensitive to light, so it is connected with the presence of the RPM, whereas the polar compass is insensitive to light and therefore must use other mechanisms of magnetoreception, probably related to the MBM (Ritz et al. 2002; Wajnberg et al. 2010). To determine directions, the inclination compass uses the angle between the geomagnetic vector and the surface of the planet. It is worth noticing that animals which use this type of compass do not differentiate between north and south, but only between the direction 'to the pole' and 'to the equator'. Therefore, changes in the vertical or horizontal component of the GMF cause changes in movement directions (Wiltschko and Wiltschko 1996). Animals which use the inclination compass include insects, amphibians, sea turtles (Lohmann 1991; Lohmann and Lohmann 1993) and birds (Wiltschko and Wiltschko 2006; Vacha et al. 2008). The polar compass, which is based on the perception of the horizontal component of the GMF, does not sense changes in the vertical component. So, animals which use it, can differentiate between the north and the south pole (Wiltschko and Wiltschko 1996). This group features crustaceans, bony fish, and mammals (Lohmann et al. 1995; Wiltschko and Wiltschko 2006). However, during long-distance migrations, the magnetic compass alone is often insufficient for accurate navigation. It has been confirmed that both the inclination and the intensity of the GMF in a given place on Earth may constitute a source of information for the animal on its exact location (Lohmann et al. 2007). In a way, this natural navigation system may provide animals with information on their geographic location and help them choose the correct route to the destination. This type of navigation is often called a magnetic map, but some scientists consider the term to be vague and misleading (Lohmann et al. 2007). Many animals that use magnetic maps, e.g. salmons (Putman et al. 2013, 2014a, 2014b; Scanlan et al. 2018; Lohmann and Lohmann 2019) and sea turtles (Lohmann et al. 2001, 2004, 2012; Putman et al. 2011; Lohmann and Lohmann 2019) are able to periodically update their magnetic map in vital areas, i.e. nesting sites, while visiting them, and thus avoid or reduce the number of errors that might occur due to the secular variation (Brothers and Lohmann 2015; Lohmann and Lohmann 2019). Although little is still known what operational principles these systems adhere to, it is assumed that there are various types of magnetic maps, 
for example one- and two-dimensional. One-dimensional maps are simpler and based on changes of only one parameter of the GMF, either inclination or intensity. However, in favourable conditions, the map may be sufficient for locating any point on Earth (Lohmann and Lohmann 2006) and some sea turtles are thought to be using this type of magnetic map (Lohmann et al. 2007). Two-dimensional maps are based on both parameters (inclination and intensity) simultaneously. Moreover, some animals may use different magnetoreception strategies at different stages of their lives. For instance, young turtles, Caretta caretta (Linnaeus 1758) are believed to use two- dimensional magnetic maps based on a system of magnetic orientation points of a given/relevant inclination and intensity. On the other hand, mature turtles use one-dimensional map and move along isolines of the GMF until they reach their destination (Lohmann et al. 2007). Nevertheless, it should be remembered that most animals probably do not see any map image; instead, they compare the intensity and/or inclination of the GMF in a given place with the data of their destination (Lohmann et al. 2007).

\section{Animal Magnetonavigation}

Regardless of which map animals use, one- or two-dimensional, they navigate in three different ways. Firstly, they move towards a known point according to the gradient of the inclination and/or intensity of the GMF, e.g. young green sea turtles (Chelonia mydas Linnaeus, 1758) (Avens and Lohmann 2004; Lohmann and Putman 2007), and the Caribbean spiny lobster (Panulirus argus Latreille, 1804) (Boles and Lohmann 2003; Lohmann et al. 2007). Secondly, they find an isoline and move along it until they find the desired location, e.g. sea turtles (Lohmann et al. 2007, 2008; Brothers and Lohmann 2015). Finally, some animals may also utilise the strategy of moving according to orientation points, i.e. areas with remembered parameters of the GMF, where they change the direction of the movement, e.g. nightingales Luscinia luscinia (Linnaeus, 1758; Fransson et al. 2001; Kullberg et al. 2003; Lohmann et al. 2007) and rock pigeons Columba livia Gmelin, 1789. For short distances, rock pigeons use orientation points they know and move along known routes, even if they are longer than the optimal way (Biro et al. 2004). On top of that, some animals combine two of these scenarios. For example, the European pied flycatcher Ficedula hypoleuca (Pallas, 1764) uses orientation points on the route from Central Europe to Spain, and it changes the direction and goes towards a known point in the Central Sahara according to the gradient of the inclination and/ or intensity of the field (Lohmann et al. 2007).

Magnetonavigation is also used at different distances. Long-distance navigation was studied on monarch butterflies Danaus plexippus (Linnaeus, 1758) (Wajnberg et al. 2010), sharks (Klimley 1993), sockeye salmons Oncorhynchus tnerka (Walbaum, 1792) (Walker 1997) and robins (Wiltschko and Merkel 1966). Also, cetaceans determine directions during their long migrations using the GMF (Walker 1992). Then, shorter distances are covered by the Caribbean spiny lobster (Boles and Lohmann 2003; Lohmann et al. 2007), ants Pachycondyla marginata Roger, 1861 (Wajnberg et al. 2010) and the salamander Notophthalmus viridescens (Rafinesque, 1820) (Fisher et al. 2001; Phillips et al. 2002; Lohmann et al. 2007).

Yet, the magnetic sense does not have to be connected only with migrations. For example, mammals from the family Spalacidae, Spalax ehrenbergi (Nehring, 1898), and mole rats from the genus Cryptomys which spend most of their life underground, use navigation to move inside their burrows (Kimchi et al. 2004), while honey bees use magnetic stimuli as a source of information on the location of food sources, and worker bees are able to 
pass this information to one another and such a transfer most probably also includes the GMF data (Wajnberg et al. 2010). An interesting example is also magnetic alignment, which means that an animal aligns its body axis with the lines of the GMF, as it was observed in many invertebrate and vertebrate species. This intriguing behaviour is demonstrated by animals very well-known for their magnetonavigation abilities, such as birds (Bianco et al. 2019), but also many species of mammals whose magnetonavigation abilities have not been considered, yet. For instance, cattle, the European roe deer and red deer position themselves along the north-south axis when resting or feeding (Begall et al. 2008; Burda et al. 2009; Slaby et al. 2013; Belova and Acosta-Avalos 2015). Similarly, dogs align their body along the north-south axis during defecation (Yosef et al. 2020). In fact, numerous studies show that among vertebrates magnetic alignment behaviour typically coincides with the north-south magnetic axis, but mean directional preferences of animals are often rotated clockwise from the north-south axis (Malkemper et al. 2016; Červený et al. 2011; Begall et al. 2013; Hart et al. 2013). Still, mechanisms of this phenomenon and its possible adaptive significance remain unknown (Malkemper et al. 2016). Also, research reveal that animals use the GMF to some degree when they select locations for their lairs and rutting (Tombarkiewicz et al. 2010). It has also been proven that deer, wild boars and otters prefer areas free of the GMF disturbances for their lairs and burrows. On the other hand, badgers select areas of the inhomogeneous magnetic field for their burrows (Tombarkiewicz et al. 2010), whereas it is suggested that compass termites (Amitermes meridionalis Froggatt, 1898) may build and repair their mounds by using magnetic cues (Jacklyn and Munro 2002).

Magnetoreceptors have been noticed in many species that do not display behaviour dependent on the GMF. Magnetite, maghemite and hematite crystals (see section 'Magnetoreception') have also been discovered in the human brain (Yang et al. 2017; Gorobets et al. 2017; Posfai and Dunin-Borkowski 2009), and cryptochromes (see section 'Magnetoreception') in retina (Kirschvink et al. 1992). These magnetoreceptors have been confirmed to be active (Foley et al. 2010), however, their purpose remains yet to be addressed (Nishimura et al. 2014).

In conclusion, most animals, if not all, including humans possess at least one of the above magnetoreception mechanisms which enable or can enable magnetonavigation. According to the available data, animals use their magnetoreceptors to a different extent, but the very fact they exist means that the GMF detection is very important.

\section{Magnetoreception of Plants and Fungi}

Currently, plant magnetoreception mechanisms are thought to be similar to those found in animals, i.e. magnetoreception based on the presence of ferromagnetic crystals (MBM) or the RPM connected with the presence of cryptochromes. Besides, a mechanism based on ion cyclotron resonance is proposed as an alternative explanation of magnetoreception in plants (Galland and Pazur 2005).

An example of plant magnetoreception is demonstrated by roots of some plants which are oriented along the east-west axis. Wheat (Triticum aestivum Linnaeus, 1753) roots grow parallel to the horizontal component of the GMF, whereas storage roots of beet (Beta vulgaris Linnaeus, 1753) grow in the direction of the GMF activity (Galland and Pazur 2005). Then, it has been shown that seeds placed with their longer axis parallel to the lines of the GMF germinate and grow faster (Kobayashi et al. 2004), e.g. barley (Hordeum vulgare 
Linnaeus, 1753), common flax, oat (Avena sativa Linnaeus, 1753), rye, maize (Zea mais Linnaeus, 1753), pea, and wheat (Galland and Pazur 2005; Pittman 1963).

In the case of magnetoreception and magnetonavigation in fungi little is known and studies on this topic have been extremely limited (Pazur et al. 2007).

\section{The Impact of the Geomagnetic Reversal}

The GMF has properties of a constant field; however, it undergoes periodic changes. These include temporary disturbances caused by magnetic storms as well as long-term alternations, e.g. a drift of geomagnetic poles (Dubrov 1978; World Data Center for Geomagnetism 2012; Livermore et al. 2020). It also experiences changes in the location of the magnetic poles, called the geomagnetic reversal (GMF reversal) or polarity reversal, which occur every several dozen thousands to several million years (Dubrov 1978, Prévot et al. 1985, Panovska et al. 2019). Though it has never happened during the existence of human civilisation, other hominids were witnesses to the last GMF reversal nearly 780 thousand years ago (Panovska et al. 2019).

We do not know the exact nature of the GMF reversal. The only remnants of this phenomenon are paleomagnetic records in the rocks. There are many hypotheses and theoretical models. Most of them suggest that the GMF reversal is a slow phenomenon lasting from 2,000 to 12,000 years, on average ca. 7000 years (Glassmeier and Vogt 2010; Clement 2004; Glatzmaier and Coe 2015). Some models assume that during the GMF reversal, Earth's magnetic field decreases to ca. $10 \%$ of its current value (Glassmeier and Vogt 2010), because its internal component, whose GMF value amounts to 90-95\%, disappears.

It is worth noticing that not all of polarity changes are fully stable, as soon after the reversal the GMF returns to its previous polarity. Owing to such instabilities, some scientists classify those events as geomagnetic excursions, not as the GMF reversals (Panovska et al. 2019). Geomagnetic excursions are relatively short (a few hundred to more than 10 thousand years) changes in the field intensity of low latitude (up to $45^{\circ}$ from the previous position) or even full reverses, but with the GMF returning to its previous polarity (Panovska et al. 2019). Although the mechanisms driving the excursions and their relation to the GMF reversals are not fully understood, their 'rapid' nature makes them potentially harmful to life (Cooper et al. 2021).

The question is whether the GMF reversal can affect life on Earth. As early as in 1963, it was postulated by Uffen (Uffen 1963) that the weakening of the GMF would release particles trapped in the Van Allen radiation belts, which would strike Earth's surface directly, and thus bring about changes and instability of the atmosphere. This would trigger significant climate change and destabilisation of the ozone layer, which would lead to an increase of ionizing radiation including the UV radiation (Valkovic 1977). Also, because of the overall impact of the GMF on living organisms, a majority of the GMF changes would lead to a long-term deterioration of individual organisms' health. Additionally, a lack of inverted magnetic poles could be problematic for organisms which use the GMF for navigation as their migration could be disturbed.

Yet, another question arises whether the GMF reversal could affect the health of individual specimens as well as entire populations, and eventually cause mass extinction, as some scientists suggest. Regretfully, there is no satisfactory answer. The GMF reversal is an environmental change of an enormous scale, and definitely it can impact many elements of the biosphere. Historically, some GMF reversals were believed to be followed by 
the emergence of new groups of organisms (Glassmeier and Vogt 2010), and several mass extinctions can be attributed to the GMF reversal, e.g. the Cretaceous-Paleogene mass extinction coincided with the GMF reversal (Crain 1971), however, Glassmeier and Vogt undermine the validity of such correlations (Glassmeier and Vogt 2010). In more recent studies new interconnection were noted. Wei and colleagues suggested a possible link between the increase of the GMF reversal frequency, observed decrease in oxygen level and marine species extinctions (Wei et al. 2014). Similarly, the Ediacaran extinction event is believed to have been caused by the GMF reversal (Meert et al. 2016). Present-day studies imply that geomagnetic excursions, e.g. Laschamp excursion (41 to 42 thousand years ago) and excursions identified in sediments of Brunhes Chron (nearly 13 thousand years ago) could have led to a regional extinction of large mammals (Channell and Vigliotti 2019). According to Cooper et al. (2021), the Laschamp excursion in combination with the Grand Solar Minima, initiated substantial changes in the concentration and circulation of the atmospheric ozone, increased atmospheric ionisation and ultraviolet (UV) radiation levels, leading to global climate shifts that caused major environmental changes. It was also suggested that those environmental changes could have sparked a chain of events leading to the extinction of large mammals in Australia and Europe, and possibly to the extinction of Homo neanderthalensis (King 1864) and subsequent success of Homo sapiens Linnaeus 1758 (Channell and Vigliotti 2019; Cooper et al. 2021). Similarly, large mammals' extinctions in North America and Europe 13 thousand years ago could be linked to geomagnetic excursions identified in sediments of Brunhes Chron.

Truth be told that even with these new premises, we still operate more in the realms of speculation. The existence of a link between polarity transitions and mass extinctions is possible, and the topic is worthy of a debate, however, new multidisciplinary studies are indispensable if we want to come closer to the final conclusion.

\section{Implications for Astrobiology}

A comparison between Earth and its two neighbouring rocky planets makes us fully aware of why astrobiologists assume that the planet's possession of a stable planetary magnetic field (PMF) is considered to be a key factor determining the habitability of the very planet (Lammer et al. 2009; Cuartas 2018).

Planetary habitability is a measure of a celestial body's ability to provide conditions suitable for the emergence and maintenance of life on its surface (Meadows and Barnes 2018). There are many factors influencing habitability of a planet (Papagiannis 1992; Lammer et al. 2009): ranging from proper characteristics of the parenting star, the mass and size of the given celestial body, its distance from the star and its spinning rate, to plate tectonics and properties of the atmosphere (Papagiannis 1992; Lammer et al. 2009). However, five features seem to be the most essential for the origins and development of life: most importantly liquid water (Meadows and Barnes 2018), ensured by stable temperatures, atmosphere, sources of energy and nutrients (Papagiannis 1992; Meadows and Barnes 2018). At least three of these features seems to be more likely to find on planets with the stable PMF (in the case of Earth the GMF), like it was shown by comparison of Venus, Earth, and Mars (see section 'The geomagnetic field and origins of life on Earth'). Still, the problem is that unlike planets and moons of our Solar System, whose PMFs have been measured to some extent (Bland et al. 2008), exoplanets are currently impossible to be studied with regard to direct measurements of their PMFs, therefore precise predictions of structure and the source 
of energy of those PMF are impossible to make (Cuartas 2018). So, to prepare models of those celestial bodies' PMFs, some suppositions in terms of the possible composition and structure should be considered (Cuartas 2018; Zuluaga and Bustamante 2018).

Another issue that needs addressing from the point of view of astrobiology and future space missions is how terrestrial life could survive while living in magnetic conditions different from the GMF, e.g. in hypomagnetic conditions. Should Earth's organisms, simple or complex, be able to survive in hypomagnetic conditions, manned space flights and planetary protection policies would be affected (Erdmann et al. 2021). In this context, studies on the influence of the GMF and/or hypomagnetic conditions on Earth's organisms (especially extremophiles) is of high importance (Erdmann et al. 2021).

\section{Conclusions}

The geomagnetic field (GMF) protects Earth from the solar wind and cosmic rays. In this way it helps to maintain Earth's atmosphere and the ozone layer, ultimately stabilising conditions on our planet and regulating the amount of energy reaching its surface. The influence of the GMF on living organisms cannot be underestimated, because they are negatively affected by hypomagnetic conditions. Organisms developed magnetoreception on the basis of the radical pair mechanism (RPM), and therefore the GMF has become an exceptional source of positional information. Thanks to this ability, organisms are able to find most convenient habitats and rutting places not to mention migrations over huge distances.

Finally, the nature of the GMF enabled and enhanced the evolution of life on Earth. Apart from gravity, the GMF was the only relatively invariable aspect of the environment for the first organisms emerging amid dynamic changes on Earth. This notion is proved by the fact that magnetoreceptors or their relics are widespread among many organisms.

To conclude.

1. The GMF directly shields Earth from corpuscular radiation, i.e. the solar wind and cosmic rays.

2. The GMF shields Earth indirectly, by stabilising its atmosphere and the ozone layer.

3. There is a considerable body of evidence that many organisms interact with the GMF on the basis of nonspecific magnetoreception, which occurs in cells, tissues, organs, systems, as well as whole organisms.

4. Apart from gravity, the geomagnetic field is the only ubiquitous and relatively permanent element of the environment, thus being a great source of information for organisms.

5. Long-term changes in the GMF could shape environmental changes, and therefore influence the rate of evolution. Still, new multidisciplinary studies ought to be carried out in this area.

Supplementary Information The online version contains supplementary material available at https://doi. org/10.1007/s11084-021-09612-5.

Acknowledgements The authors want to thank Justyna Grześkowiak for her assistance with the English corrections of the manuscript.

Studies have been conducted in the framework of activities of BARg (Biodiversity and Astrobiology Research group). 
Authors' Contributions The concept of the article was formulated by Weronika Erdmann. Literature search was performed by Weronika Erdmann under the supervision of Łukasz Kaczmarek and Hanna Kmita. Data analyses were carried out by Weronika Erdmann, Jakub Z. Kosicki and Łukasz Kaczmarek. The first draft of the manuscript was written by Weronika Erdmann and all the authors commented on previous versions of the manuscript. All authors read and approved the final manuscript.

Funding No funding was received to support the preparation of this manuscript.

\section{Declarations}

Competing Interests The authors have no conflict of interest to declare that is relevant to the content of this article.

Open Access This article is licensed under a Creative Commons Attribution 4.0 International License, which permits use, sharing, adaptation, distribution and reproduction in any medium or format, as long as you give appropriate credit to the original author(s) and the source, provide a link to the Creative Commons licence, and indicate if changes were made. The images or other third party material in this article are included in the article's Creative Commons licence, unless indicated otherwise in a credit line to the material. If material is not included in the article's Creative Commons licence and your intended use is not permitted by statutory regulation or exceeds the permitted use, you will need to obtain permission directly from the copyright holder. To view a copy of this licence, visit http://creativecommons.org/licenses/by/4.0/.

\section{References}

Abedinpour M, Rohani R (2017) Effects of magnetized water application on soil and maize growth indices under different amounts of salt in the water. J Water Reuse Desal 7(3):319-325. https://doi.org/10. 2166/wrd.2016.216

Andre M, Norqvist P, Andersson L, Eliasson L, Eriksson AI, Bloomberg L, Erlandson RE, Waldemark J (1998) Ion energization mechanisms at $1700 \mathrm{~km}$ in the auroral region. J Geophys Res 103(A2):41994222. https://doi.org/10.1029/97JA00855

Avens L, Lohmann KJ (2004) Navigation and seasonal migratory orientation in juvenile sea turtles. J Exp Biol 207(11):1771-1778. https://doi.org/10.1242/jeb.00946

Bazylinski AD, Schlizinger DR, Howes BH, Frankel RB, Epstein SS (2000) Occurence and distribution of diverse populations of magnetic protists in a chemically stratified salt pond. Chem Geol 168(34):319-328. https://doi.org/10.1016/S0009-2541(00)00211-4

Bazylinski DA, Frankel RB (2004) Magnetosome formation in prokaryotes. Nat Rev Microbiol 2(3):217230. https://doi.org/10.1038/nrmicro842

Becker RO (1963) Relationship of geomagnetic environment to human biology. New York State J Med 63:2215-2219

Begall S, Cerveny J, Neef J, Vojtech O, Burda H (2008) Magnetic alignment in grazing and resting cattle and deer. PNAS 105(36):13451-13455. https://doi.org/10.1073/pnas.0803650105

Begall S, Malkemper EP, Červený J, Němec P, Burda H (2013) Magnetic alignment in mammals and other animals. Mammal Biol 78:10-20. https://doi.org/10.1016/j.mambio.2012.05.005

Beischer DE (1964) Biological effects of magnetic fields in their relation to space travel. In: Schaefer KE (ed) Bioastronautics. Macmillan, New York, pp 173-180

Belova NA, Acosta-Avalos D (2015) The effect of extremely low frequency alternating magnetic field on the behavior of animals in the presence of the geomagnetic field. J Biophys 423838. https://doi.org/10. $1155 / 2015 / 423838$

Belyaev IY, Alipov YD, Harms-Ringdahl M (1997) Effects of zero magnetic field on the conformation of chromatin in human cells. Biochim Biophys Acta 1336(3):465-473. https://doi.org/10.1016/S03044165(97)00059-7

Belyavskaya NA (2004) Biological effects due to weak magnetic field on plants. Adv Space Res 34:15661574. https://doi.org/10.1016/j.asr.2004.01.021

Belyavskaya NA (2001) Ultrastructure and calcium balance in meristem cells of pea roots exposed to extremely low magnetic fields. Adv Space Res 28(4):645-650. https://doi.org/10.1016/S02731177(01)00373-8 
Bertea CM, Narayana R, Agliassa C, Rodgers CT, Maffei ME (2015) Geomagnetic field (GMF) and plant evolution: Investigating the effects of GMF reversal on Arabidopsis thaliana development and gene expression. J vis 105(105):e53286. https://doi.org/10.3791/53286

Bianco G, Köhler RC, Ilieva M, Åkesson S (2019) Magnetic body alignment in migratory songbirds: a computer vision approach. J Exp Biol 222:jeb196469. https://doi.org/10.1242/jeb.196469

Binhi VN, Prato FS (2017) Biological effects of the hypomagnetic field: An analytical review of experiments and theories. PLoS One 12(6):e0179340. https://doi.org/10.1371/journal.pone.0179340

Binhi VN, Sarimov RM (2013) Effect of the hypomagnetic field on the size of the eye pupil. Phys Biol Phys http://arxiv.org/abs/1302. 2741

Binhi VN, Sarimov RM (2009) Zero magnetic field effect observed in human cognitive processes. Electromagn Biol Med 28:310-315. https://doi.org/10.3109/15368370903167246

Biro D, Meade J, Guilford T (2004) Familiar route loyalty implies visual pilotage in the homing pigeon. P Natl Acad Sci USA 101(50):17440-17443. https://doi.org/10.1073/pnas.0406984101

Biskup T, Schleicher E, Okafuji A, Link G, Hitomi K, Getzoff ED, Weber S (2009) Direct observation of a photoinduced radical pair in a cryptochrome blue-light photoreceptor. Angew Chem Int Ed 48:404407. https://doi.org/10.1002/anie.200803102

Bland MT, Showman AP, Tobie G (2008) The production of Ganymede's magnetic field. Icarus 198(2):384399. https://doi.org/10.1016/j.icarus.2008.07.011

Blank M, Goodman R (1997) Do electromagnetic fields interact directly with DNA? Bioelectromagnetics 18(2):111-115. https://doi.org/10.1002/(SICI)1521-186X(1997)18:2\%3c111::AID-BEM3\%3e3.0.CO;2-5

Boles LC, Lohmann KJ (2003) True navigation and magnetic maps in spiny lobsters. Nature 421(6918):6063. https://doi.org/10.1038/nature01226

Borlina CS, Weiss BP, Lima EA, Tang F, Taylor RJM, Einsle JF, Harrison RJ, Fu RR, Bell EA, Alexander EW, Kirkpatrick HM, Wielicki, MM, Harrison TM, Ramezani J, Maloof AC (2020) Reevaluating the evidence for a Hadean-Eoarchean dynamo. Sci Adv 6(15):eaav9634. https://doi.org/10.1126/sciadv. aav9634

Brothers JR, Lohmann KJ (2015) Evidence for Geomagnetic Imprinting and Magnetic navigation in the natal homing of sea turtles. Curr Biol 25:392-396. https://doi.org/10.1016/j.cub.2014.12.035

Bullard EC (1949) The magnetic field within the Earth. P Roy Soc Lond A Mat 197(1051):433-453. https:// doi.org/10.1098/rspa.1949.0074

Burda H, Begalla S, Cervený J, Neefa J, Nemec P (2009) Extremely low-frequency electromagnetic fieldsdisrupt magnetic alignment of ruminants. P Natl Acad Sci USA 106(14):5708-5713. https://doi.org/ 10.1073/pnas.0811194106

Červený J, Begall S, Koubek P, Nováková P, Burda H (2011) Directional preference may enhance hunting accuracy in foraging foxes. Biol Lett 7:355-357. https://doi.org/10.1098/rsbl.2010.1145

Chang L, Roberts AP, Williams W, Gerald JDF, Larrasoaña JC, Jovane L, Muxworthy AR (2012) Giant magnetofossils and hyperthermal events. Earth Planet Sc Lett 351-352:258-269. https://doi.org/10. 1016/j.eps1.2012.07.031

Channell JET, Vigliotti L (2019) The role of geomagnetic field intensity in Late Quaternary evolution of humans and large mammals. Rev Geophys 57(3):709-738. https://doi.org/10.1029/2018RG000629

Clark SP (1979) Pole magnetyczne Ziemi. W: Budowa Ziemi. PWN: Warszawa, Poland, 38-62

Clement BM (2004) Dependence of the duration of geomagnetic polarity reversals on site latitude. Nature 428:637-640. https://doi.org/10.1038/nature02459

Cohn F (1872) Untersuchungen u ber Bakterien. Beitr Biol Pflanz 1:127-224

Conley CC (1969) Effects of near-zero magnetic fields upon biological systems. In: Barnothy MF (eds) Biological Effects of Magnetic Fields. Springer, Boston, MA. https://doi.org/10.1007/ 978-1-4684-8352-9_2

Conley CC (1970) A Review of the biological effects of very low magnetic fields. NASA Technical Note. TND-5902:1 \pm 27 . Available at: https://ntrs.nasa.gov/citations/19700024915 (Accessed on 14/09/2016)

Cooper A, Turney CSM, Palmer J, Hogg A, Mcglone M, Wilmshurst J, Lorrey AM, Heaton TJ, Russell JM, Mccracken K, Anet JG, Rozanov E, Friedel M, Suter I, Peter T, Muscheler R, Adolphi F, Dosseto A, Faith JT, Fenwick P, Fogwill CJ, Hughen K, Lipson M, Liu J, Nowaczyk N, Rainsley E, Bronk Ramsey C, Sebastianelli P, Souilmi Y, Stevenson J, Thomas Z, Tobler R, Zech R (2021) A global environmental crisis 42,000 years ago. Science 371(6531):811-818. https://doi.org/10.1126/science.abb8677

Crain IK (1971) Possible direct causal relation between geomagnetic reversals and biological extinctions. Geol Soc Am Bull 82:2603-2606. https://doi.org/10.1130/0016-7606(1971)82[2603:PDCRBG]2.0. $\mathrm{CO} ; 2$

Cranfield CG, Dawe A, Karloukovski V, Dunin-Borkowski RE, de Pomerai D, Dobson J (2004) Biogenic magnetite in the nematode Caenorhabditis elegans. Proc Biol Sci 271:S436-439. https://doi.org/10. 1098/rsbl.2004.0209 
Cuartas PA (2018) Planetary magnetic fields and habitability in super Earths. Open Astron 27(1):183-231. https://doi.org/10.1515/astro-2018-0026

Davila AF, Fleissner G, Winklhofer M, Petersen N (2003) A new model for a magnetoreceptor in homing pigeons based on interacting clusters of superparamagnetic magnetite. Phys Chem Earth 28(1619):647-652. https://doi.org/10.1016/S1474-7065(03)00118-9

Del Seppia C, Luschi P, Ghione S, Crosio E, Choleris E, Papi F (2000) Exposure to a hypogeomagnetic field or to oscillating magnetic fields similarly reduce stress-induced analgesia in C57 male mice. Life Sci 66(14):1299-1306. https://doi.org/10.1016/S0024-3205(00)00437-9

Ding HM, Wang X, Mo WC, Qin LL, Wong S, Fu JP, Tan Y, Liu Y, He RQ, Hua Q (2019) Hypomagnetic fields cause anxiety in adult male mice. Bioelectromagnetics 40(1):27-32. https://doi.org/10.1002/ bem. 22155

Ding Y, Li J, Liu J, Yang J, Jiang W, Tian J, Li Y, Pan Y, Li J (2010) Deletion of the ftsZ-like gene results in the production of superparamagnetic magnetite magnetosomes in Magnetospirillum gryphiswaldense. J Bacteriol 192(4):1097-1105. https://doi.org/10.1128/JB.01292-09

Dubrov AP (1978) The geomagnetic field and life: Geomagnetobiology. Springer, New York City, USA

van Dyke JH, Halpern MH (1965) Observations on selected life processes in null magnetic fields. Anat Record 151:480

Ehrenberg CG (1835) Dritter Beitrag zur Erkenntniss grosser Organisation in der Richtung des kleinsten Raumes. Abh Konigl Akad Wiss Berlin 1833-1835:143-336

Erauso G, Reysenbach A, Godfroy A, Meunier JR, Crump B, Partensky F, Baross JA, Marteinsson V, Barbier G, Pace NR, Prieur D (1993) Pyrococcus abyssi sp. nov., a new hyperthermophilic archaeon isolated from a deep-sea hydrothermal vent. Arch Microbiol 160:338-349. https://doi.org/10.1007/BF00252219

Erdmann W, Idzikowski B, Kowalski W, Szymański B, Kosicki JZ, Kaczmarek Ł (2017) Can the tardigrade Hypsibius dujardini survive in the absence of the geomagnetic field? PLoS ONE 12:e0183380. https://doi.org/10.1371/journal.pone.0183380

Erdmann W, Idzikowski B, Kowalski W, Kosicki JZ, Kaczmarek Ł (2021) Tolerance of two anhydrobiotic tardigrades Echiniscus testudo and Milnesium inceptum to hypomagnetic conditions. PeerJ 9(22):e10630. https://doi.org/10.7717/peerj.10630

Ernst DA, Lohmann KJ (2016) Effect of magnetic pulses on Caribbean spiny lobsters: implications for magnetoreception. J Exp Biol 219(12):1827-1832. https://doi.org/10.1242/jeb.136036

Fernandez L, Teran Z, Leon M (1996) The effect of magnetically treated irrigation water on quality of onion seedlings grown in zeoponics. Cult Trop 17(2):55-59

Fesenko EE, Mezhevikina LM, Osipenko MA, Gordon RY, Khutzian SS (2010) Effect of the "zero" magnetic field on early embryogenesis in mice. Electromagn Biol Med 29:1-8. https://doi.org/10.3109/ 15368371003627290

Finlay CC, Maus S, Beggan CD, Bondar TN, Chambodut A, Chernova TA, Chulliat A, Golovkov VP, Hamilton B, Hamoudi M, Holme R, Hulot G, Kuang W, Langlais B, Lesur V, Lowes FJ, Lühr H, Macmillan S, Mandea M, McLean S, Manoj C, Menvielle M, Michaelis I, Olsen N, Rauberg J, Rother M, Sabaka TJ, Tangborn A, Tøffner-Clausen L, Thébault E, Thomson AWP, Wardinski I, Wei Z, Zvereva TI (2010) International Geomagnetic Reference Field: the eleventh generation. Geophys J Int 183(3):1216-1230. https:// doi.org/10.1111/j.1365-246X.2010.04804.X

Fisher JH, Freake MJ, Borland SC, Phillips JB (2001) Evidence for the use of magnetic map information by an amphibian. Anim Behav 62(1):1-10. https://doi.org/10.1006/anbe.2000.1722

Fleming JA (1939) Progress-report on researches in Terrestrial Magnetism and Electricity at Department of Terrestrial Magnetism, Carnegie Institution of Washington, for Year April 1938 to March 1939. Eos Trans AGU 20(3):394-397

Foley LE, Gegear RJ, Reppert SM (2010) Human cryptochrome exhibits light-dependent magnetosensivity. Nat Commun 2(356):1-3. https://doi.org/10.1038/ncomms1364

Frankel RB, Blakemore RP, Wolfe RS (1979) Magnetite in freshwater magnetotactic bacteria. Science 203(4387):1355-1356. https://doi.org/10.1126/science.203.4387.1355

Fransson T, Jakobsson S, Johansson P, Kullberg C, Lind J, Vallin A (2001) Magnetic cues trigger extensive refuelling. Nature 414(6859):35-36. https://doi.org/10.1038/35102115

Froggatt WW (1898) Australian Termitidae. Part 111. Proc. Linn. Soc. N.S. W. 22:721-758

Fu JP, Mo WC, Liu Y, He RQ (2016) Decline of cell viability and mitochondrial activity in mouse skeletal muscle cell in a hypomagnetic field. Bioelectromagnetics 37(4):212-222. https://doi.org/10.1002/ bem. 21968

Futaana Y, Barabash S, Yamauchi Y, McKenna-Lawlor S, Lundin R, Luchmann JG, Brain D, Carlsson E, Sauvaud JA, Winninghame D, Frahm RA, Wurz P, Holmström M, Gunell H, Kallio E, Baumjohann W, Lammer H, Sharber JR, Hsieh KC, Andersson H, Grigoriev A, Brinkfeldt K, Nilsson H, Asamura K, Zhang TL, Coates AJ, Linder DR, Kataria DO, Curtis CC, Sandel BR, Fedorov A, Mazelle C, 
Thocaven JJ, Grande M, Koskinen HEJ, Sales T, Schmidt W, Riihela P, Kozyra J, Krupp N, Woch J, Fränz M, Dubinin E, Orsini S, Cerulli-Irelli R, Mura A, Milillo A, Maggi M, Roelof E, Brandt P, Szego K, Scherrer J, Bochsler P (2008) Mars Express and Venus Express multi-point observations of geoeffective solar flare events in December 2006. Planet Space Sci 56(6):873-880. https://doi.org/10. 1016/j.pss.2007.10.014

Galland P, Pazur A (2005) Magnetoreception in plants. J Plant Res 118(6):371-389. https://doi.org/10.1007/ s10265-005-0246-y

Galvin AB, Ipavich FM, Gloeckler G, Coplan A, Hovestadt D, Hilchenbach M, Buergi A, Klecker B, Scholer M, Bochsler P, Balsiger H, Geiss J (1996) Solar Wind Composition: First Results from SOHO and Future Expectations. In: American Astronomical Society, $188^{\text {th }}$ Meeting Abstracts. BAAS 28:897

Gargaud M, Martin H, López-García P, Montmerle T, Pascal R (2012) Young Sun, early Earth and the origins of life. Springer, New York City, USA, p 96

Gehring AU, Kind J, Charilaou M, García-Rubio I (2011) The detection of magnetotactic bacteria and magnetofossils by means of magnetic anisotropy Earth Planet. Sci Lett 309(1):113-117. https://doi.org/ 10.1016/j.eps1.2011.06.024

Geiss J, Gloeckler G, Von Steiger R (1995) Origin of the solar wind from composition data. Space Sci Rev 72:49-60. https://doi.org/10.1007/BF00768753

Glassmeier KH, Vogt J (2010) Magnetic polarity transitions and biospheric effects. Space Sci Rev 155(14):387-410. https://doi.org/10.1007/s11214-010-9659-6

Glatzmaier GA, Coe RS (2015) Magnetic polarity reversals in the core. In: Schubert G (ed) Treatise on Geophysics 2nd edn, Elsevier, Amsterdam, Netherlands pp 279-295. https://doi.org/10.1016/B978044452748-6.00135-8

Gorobets O, Gorobets S, Koralewski M (2017) Physiological origin of biogenic magnetic nanoparticles in health and disease: From bacteria to humans. Int J Nanomed 12:4371-4395. https://doi.org/10.2147/ IJN.S130565

Hand E (2016) What and where are the body's magnetometers? Science 352(6293):1510-1511. https://doi.org/ 10.1126/science.352.6293.1510

Hart V, Červený J, Novakova P, Malkemper EP, Begall S, Hanzal V, Jezek M, Kusta T, Nemcova V, Adamkova J, Benediktova K, Cerveny J, Burda H (2013) Dogs are sensitive to small variations of the Earth's magnetic field. Front Zool 10(1):80. https://doi.org/10.1186/1742-9994-10-80

Hore PJ, Mouritsen H (2016) The radical pair mechanism of magnetoreception. Annu Rev Biophys 45:299_ 344. https://doi.org/10.1146/annurev-biophys-032116-094545

Jacklyn PM, Munro U (2002) Evidence for the use of magnetic cues in mound construction by the termite Amitermes meridionalis (Isoptera: Termitinae). Aust J Zool 50:357-368. https://doi.org/10.1071/ ZO01061

Janicki JS (2008) Magnetobiologia, Podstawowe procesy zachodzące w organizmie pod wpływem pola magnetycznego. In Zastosowanie stałych pól magnetycznych w terapii. IBF Primax Medica: Poznań, Poland 15-21, 30-46

Johnsen S, Lohmann KJ (2008) Magnetoreception in animals. Physics Today 61(3):29 ISSN 0031-9228. https://doi.org/10.1063/1.2897947

Juutilainen J, Herrala M, Luukkonen J, Naarala J, Hore PJ (2018) Magnetocarcinogenesis: is there a mechanism for carcinogenic effects of weak magnetic fields? Proc Biol Sci 285(1879):20180590. https://doi. org/10.1098/rspb.2018.0590

Kalmijn A (1981) Biophysics of geomagnetic field detection. IEEE Trans Magn 17(1):1113-1124. https:// doi.org/10.1109/TMAG.1981.1061156

Kimchi T, Etienne AS, Terkel J (2004) A subterranean mammal uses the magnetic compass for path integration. PNAS 101(4):1105-1109. https://doi.org/10.1073/pnas.0307560100

King W (1864) On the Neanderthal Skull, or reasons for believing it to belong to the Clydian Period and to a species different from that represented by man. Report of the British Association for the Advancement of Science, Notices and Abstracts, Newcastle-upon-Tyne 1863:81-82

Kirschvink JL, Jones DS, MacFadden BJ (1985) Magnetite biomineralization and magnetoreception in organisms: A new biomagnetism. Springer, New York

Kirschvink JL, Kobayashi-Kirschvink A, Woodford BJ (1992) Magnetite biomineralization in the human brain. PNAS 89(16):7683-7687. https://doi.org/10.1073/pnas.89.16.7683

Klimley AP (1993) Highly directional swimming by scalloped hammerhead sharks, Sphyrna lewini, and subsurface irradiance, temperature, bathymetry, and geomagnetic field. Mar Biol 117(1):1-22. https:// doi.org/10.1007/BF00346421

Kobayashi M, Soda N, Miyo T, Ueda Y (2004) Effects of combined DC and AC magnetic fields on germination of hornwort seeds. Bioelectromagnetics 25(7):552-559. https://doi.org/10.1002/bem.20032 
Kopp RE, Kirschvink JL (2008) The identification and biogeochemical interpretation of fossil magnetotactic bacteria. Earth-Sci Rev 86(1-4):42-61. https://doi.org/10.1016/j.earscirev.2007.08.001

Krasnopolsky VA, Parshev VA (1981) Chemical composition of the atmosphere of Venus. Nature 292(5824):610-613. https://doi.org/10.1038/292610a0

Kullberg C, Lind J, Fransson T, Jakobsson S, Vallin A (2003) Magnetic cues and time of season affect fuel deposition in migratory thrush nightingales (Luscinia luscinia). P Roy Soc B-Biol Sci 270(1513):373-378. https://doi.org/10.1098/rspb.2002.2273

Lammer H, Bredehöft JH, Coustenis A, Khodachenko ML, Kaltenegger L, Grasset O, Prieur D, Raulin F, Ehrenfreund P, Yamauchi M, Wahlund JE, Grießmeier JM, Stangl G, Cockell CS, Kulikov YN, Grenfell JL, Rauer H (2009) What makes a planet habitable? Astron Astrophys Rev 17(2):181249. https://doi.org/10.1007/s00159-009-0019-z

Lammer H, Lichtenegger H, Biernat H, Erkaev N, Arshukova I, Gunell H, Lukyanov A, Holmstrom M, Barabash S, Zhang TL, Baumjohann W (2006) Loss of hydrogen and oxygen from the upper atmosphere of Venus. Planet Space Sci 54(13):1445-1456. https://doi.org/10.1016/j.pss.2006.04. 022

Lammer H, Zerkle AL, Gebauer S, Tosi N, Noack L, Scherf M, Pilat-Lohinger E, Güdel M, Grenfell JL, Godolt M, Nikolaou A (2018) Origin and evolution of the atmospheres of early Venus. Earth and Mars Astron Astrophys Rev 26(1):2. https://doi.org/10.1007/s00159-018-0108-y

Latreille PA (1804) Des Langoustes du Museum national d'Histoire naturelle. Ann Mus Hist Nat Paris 3:388-395

Lefevre CT, Bernadac A, Yu-Zhang K, Pradel N, Wu LF (2009) Isolation and characterization of a magnetotactic bacterial culture from the Mediterranean Sea. Environ Microbiol 11:1646-1657. https:// doi.org/10.1111/j.1462-2920.2009.01887.x

LiboffWilliams ARTJr, Strong DM, Wistar RJr (1984) Time-varying magnetic fields: effect on DNA synthesis. Science 223:818-820. https://doi.org/10.1126/science.6695183

Linnaeus C (1753) Species plantarum, exhibentes plantas rite cognitas, ad genera relatas, cum differentiis specificis, nominibus trivialibus, synonymis selectis, locis natalibus, secundum systema sexuale digestas. Impensis Laurentii Salvii, Holmiae (Stockholm), Sweden, Vol 2, pp: [i], 561-1200, [1-30, index], [i, err.]

Linnaeus C (1758) Systema Naturae per regna tria naturae, secundum classes, ordines, genera, species, cum characteribus, differentiis, synonymis, locis. Editio decima, reformata, 10th revised edition, Impensis Laurentii Salvii, Holmiae (Stockholm), Sweden, vol 1 pp 824

Livermore PW, Finlay CC, Bayliff M (2020) Recent north magnetic pole acceleration towards Siberia caused by flux lobe elongation. Nat Geosci 13:387-391. https://doi.org/10.1038/ s41561-020-0570-9

Lohmann KJ (1991) Magnetic orientation by hatchling loggerhead sea turtles (Caretta caretta). J Exp Biol 155:37-49

Lohmann KJ, Lohmann CMF (1993) A light-independent magnetic compass in the leatherback sea turtle. Biol Bull 185:149-151. https://doi.org/10.2307/1542138

Lohmann KJ, Lohmann CMF (2006) Sea turtles, lobsters, and oceanic magnetic maps. Mar Freshw Behav Phy 39(1):49-64. https://doi.org/10.1080/10236240600563230

Lohmann KJ, Lohmann CMF (2019) There and back again: Natal homing by magnetic navigation in sea turtles and salmon. J Exp Biol 222(1):jeb184077. https://doi.org/10.1242/jeb.184077

Lohmann KJ, Pentcheff ND, Nwvitt GA, Stetten GD, Zimmer-Faust RK, Jarrard HE, Boles LC (1995) Magnetic orientation of spiny lobsters in the ocean: experiments with undersea coil systems. J Exp Biol 198(10):2041-2048

Lohmann KJ, Cain SD, Dodge SA, Lohmann CMF (2001) Regional magnetic fields as navigational markers for sea turtles. Science 294:364-366. https://doi.org/10.1126/science.1064557

Lohmann KJ, Lohmann CMF, Ehrhart LM, Bagley DA, Swing T (2004) Geomagnetic map used in seaturtle navigation. Nature 428:909-910. https://doi.org/10.1038/428909a

Lohmann KJ, Lohmann CMF, Putman NF (2007) Magnetic maps in animals: nature's GPS. J Exp Biol 210(21):3697-3705. https://doi.org/10.1242/jeb.001313

Lohmann KJ, Putman NF, Lohmann CMF (2008) Geomagnetic imprinting: A unifying hypothesis of long-distance natal homing in salmon and sea turtles. Proc Natl Acad Sci USA 105:19096-19101

Lohmann KJ, Putman NF, Lohmann CMF (2012) The magnetic map of hatchling loggerhead sea turtles. Curr Opin Neurobiol 22:336-342. https://doi.org/10.1016/j.conb.2011.11.005

Lowenstamm HA (1962) Magnetite in denticle capping in recent chitons (Polyplacophora). Geol Soc Am Bull 73(4):435-438. https://doi.org/10.1130/0016-7606(1962)73[435:MIDCIR]2.0.CO;2 
Luhmann JG, Bauer SJ (1992) Solar wind effects on atmospheric evolution at Venus and Mars, in Venus and Mars: Atmospheres, Ionospheres, and Solar Wind Interactions. AGU Monograph 66:417-430. https://doi.org/10.1029/GM066p0417

Magnetic North, Geomagnetic and Magnetic Poles, on World Data Center for Geomagnetism, Kyoto (2012) http://wdc.kugi.kyoto-u.ac.jp/poles/polesexp.html (Accessed: 08/09/2016)

Malkemper EP, Painter MS, Landler L (2016) Shifted magnetic alignment in vertebrates: Evidence for neural lateralization? J Theor Biol 399(2016):141-147. https://doi.org/10.1016/j.jtbi.2016.03.040

Maratea D, Blakemore RP (1981) Aquaspirillum magnetotacticum sp. nov., a magnetic Spirillum. Int J Syst Bacteriol 31(4):452-455. https://doi.org/10.1099/00207713-31-4-452

Markov MS, Pilla AA (1994) Static magnetic field modulation of myosin phosphorylation: Calcium dependence in two enzyme preparations. Bioelectroch Bioener 35(1-2):57-61. https://doi.org/10.1016/03024598(94)87012-8

Markov MS, Pilla AA (1997) Weak static magnetic field modulation of myosin phosphorylation in a cellfree preparation: Calcium dependence. Bioelectroch Bioener 43(2):233-238. https://doi.org/10.1016/ S0302-4598(96)02226-X

McElroy MB, McConnell JC (1971) Nitrous oxide: A natural source of stratospheric NO. J Atmos Sci 28:1095-1098. https://doi.org/10.1175/1520-0469(1971)028\%3C1095:NOANSO\%3E2.0.CO;2

McNish AG (1940) Physical representations of the geomagnetic field. Eos Trans AGU 21(2):287-291. https://doi.org/10.1029/TR021i002p00287

Meadows VS, Barnes RK (2018) Factors affecting exoplanet habitability. In: Deeg H, Belmonte J. (eds) Handbook of Exoplanets. Springer, Cham. https://doi.org/10.1007/978-3-319-30648-3_57-1

Medikus FK (1787) Cracca. Vorles Churpf Phys Ges 2:361

Meert JG, Levashova NM, Bazhenov ML, Landing E (2016) Rapid changes of magnetic field polarity in the late Ediacaran: linking the Cambrian evolution-ary radiation and increased UV-B radiation. Gondwana Res 34:149-157. https://doi.org/10.1016/j.gr.2016.01.001

Meigen JW (1830) Systematische Beschreibung der bekannten europäischen zweiflügeligen Insekten. Schulzische Buchhandlung, Hamm, Volume 6(iii-xi):1-401 + 24 unnumbered pages.

Mewaldt RA (1996) Cosmic Rays. In MacMillan Encyclopedia of Physics. 1st ed., Rigden, J.S., Macmillan Inc.: New York City, NY, USA, vol 1, pp 278-280

Michalski G, Bhattacharya SK, Girsch G (2014) NOx cycle and the tropospheric ozone isotope anomaly: an experimental investigation. Atmos Chem Phys 13(4):9443-9483. https://doi.org/10.5194/ acp-14-4935-2014

Migula W (1895) Bacteriaceae (Stäbchenbacterien) In: Engler A (ed) Die Natürlichen Pflanzenfamilien, W. Engelmann, Leipzig, Germany 1(Ia) pp 20-30

Mika T (1996) Charakterystyka fizyczna pola magnetycznego. In: Fizykoterapia. Podręcznik dla Wydziałów Fizjoterapii Medycznych Studiów Zawodowych. Wydawnictwo Lekarskie PZWL, Warsaw, Poland, pp 325-330

Miller SL, Urey HC (1959) Organic compound synthesis on the primitive Earth. Science 130(3370):245-251

Mo WC (2012) Altered development of Xenopus embryos in a hypogeomagnetic field. Bioelectromagnetics 33(3):238-246. https://doi.org/10.1002/bem.20699

Mo WC, Zhang ZJ, Liu Y, Zhai GJ, Jiang YD, He RQ (2011) Effects of a hypogeomagnetic field on gravitropism and germination in soybean. Adv Space Res 47(9):1616-1621. https://doi.org/10.1016/j.asr. 2010.12.024

Mo WC, Zhang ZJ, Liu Y, Bartlett PF, He RQ (2013) Magnetic shielding accelerates the proliferation of human neuroblastoma cell by promoting G1-phase progression. PLoS One 8(1)e54775. https://doi. org/10.1371/journal.pone.0054775

Mo WC, Liu Y, Bartlett PF, He RQ (2014a) Transcriptome profile of human neuroblastoma cells in the hypomagnetic field. Sci China Life Sci 57(4):448-461. https://doi.org/10.1007/s11427-014-4644-Z

Mo WC, Liu Y, He RQ (2014b) Hypomagnetic field, an ignorable environmental factor in space? Sci China Life Sci 57(7):726-728. https://doi.org/10.1007/s11427-014-4662-X

Mo WC, Zhang Z, Wang D, Liu Y, Bartlett PF, He RQ (2016) Shielding of the geomagnetic field alters actin assembly and inhibits cell motility in human neuroblastoma cells. Sci Rep 6:22624. https://doi.org/10. $1038 /$ srep 22624

Mouritsen H (2018) Long-distance navigation and magnetoreception in migratory animals. Nature 558:5059. https://doi.org/10.1038/s41586-018-0176-1

Nanush'yan ER, Murashev VV (2003) Induction of multinuclear cells in the apical meristems of Allium cepa by geomagnetic field outrages. Russ J Plant Physl 50(4):522-526. https://doi.org/10.1023/A: 1024729008858 
Negishi Y, Hashimoto A, Tsushima M, Dobrota C, Yamashita M, Nakamura T (1999) Growth of pea epicotyl in low magnetic field: implication for space research. Adv Space Res 23(12):2029-2032. https:// doi.org/10.1016/s0273-1177(99)00342-7

Nehring A (1898) Über mehrere neue Spalax Arten. Sber Ges Naturf Freunde Berl 10:163-183

Nishimura T, Tada H, Nakatani E, Matsuda K, Teramukai S, Fukushima M (2014) Stronger geomagnetic fields may be a risk factor of male suicides. Psychiatry Clin Neurosci 68(6):404-409. https://doi. org/10.1111/pcn.12149

Nossol B, Buse G, Silny J (1993) Influence of weak static and $50 \mathrm{~Hz}$ magnetic fields on the redox activity of cytochrome-C oxidase. Bioelectromagnetics 14(4):361-372. https://doi.org/10.1002/bem. 2250140408

Osipenko MA, Mezhevikina LM, Krasts IV, Yashin VA, Novikov VV, Fesenko EE (2008a) Influence of "zero" magnetic field on the growth of embryonic cells and primary embryos of mouse in vitro. Biofizika 53:705-712

Osipenko MA, Mezhevikina LM, Krasts IV, Yashin VA, Novikov VV, Fesenko EE (2008b) Deterioration of murine embryonic fibroblasts and early embryos upon magnetic field deprivation. Biophysics 53(4):317-321. https://doi.org/10.1134/S0006350908040167

Ossenkopp KP, Barbeito R (1978) Bird orientation and the geomagnetic field: A review. Neurosci Biobehav Rev 2(4):255-270

Pallas PS (1764) Adumbratiunculae avium variarum praecedenti Elencho insertarum, sed quae in Systemate Naturae Illustl: Linnaei nondum extant. In: Vosmaer A (ed) Catalogue raisonné, d'une collection supérieurement belle d'Oiseaux, tant exotiques qu'Européens, de Quadrupedes et d'Insectes. Empaillés, \& arranges avec beaucoup d'art en situations \& attitudes extrèmement naturelles, \& garantis de la corruption d'une façon particulière. Le tout rassemblé \& arrangé, pendant une longue suite d'années, avec beaucoup de peines \& à gratid fraix, par A. Vroeg. Collection qu'on offre aux amateurs entiére \& à un prix raisonnable, jusqu'au 22 Septembre de cette année; aprè l'Echéance duquel terme, elle sera vendue aux plus offrands, le 6 Octobre 1764 à la Haye, dans la Maison de Mr. Costec au coin du Veenestraat sur le petit Marché am Herbes, par Pierre van Os, Libraire demeurant sur la Place à la Haye. Pieter van Os, d'Gravenhage. 1-7

Panovska S, Korte M, Constable CG (2019) One hundred thousand years of geomagnetic field evolution. Rev Geophys 57(4):1289-1337. https://doi.org/10.1029/2019RG000656

Papagiannis MD (1992) What makes a planet habitable, and how to search for habitable planets in other solar systems. J Br Interplanet Soc 45(6):227-230. (PMID: 11539468)

Pazur A, Schimek C, Galland P (2007) Magnetoreception in microorganisms and fungi. Cent Eur J Biol 2(4):597-659. https://doi.org/10.2478/s11535-007-0032-z

Phillips JB, Freake MJ, Fisher JH, Borland C (2002) Behavioral titration of a magnetic map coordinate. J Comp Physiol A 188(2):157-160. https://doi.org/10.1007/s00359-002-0286-X

Pinzon-Rodriguez A, Muheim R (2017) Zebra finches have a light-dependent magnetic compass similar to migratory birds. J Exp Biol 220(7):1202-1209. https://doi.org/10.1242/jeb.148098

Pittman UJ (1963) Magnetism and plant growth I: Effect on germination and early growth of cereal seeds. Can J Plant Sci 43(4):513-518. https://doi.org/10.4141/cjps63-104

Posfai M, Dunin-Borkowski RE (2006) Sulfides in biosystems. Reviews in Mineralogy and Geochemistry 61(1):679-714. https://doi.org/10.2138/rmg.2006.61.13

Posfai M, Dunin-Borkowski RE (2009) Magnetic nanocrystals in organisms. Elements 5(4)235-240. https://doi.org/10.2113/gselements.5.4.235

Pósfai M, Buseck PR, Bazylinski DA, Frankel RB (1998) Iron sulfides from magnetotactic bacteria: Structure, composition, and phase transitions. Am Mineral 83(11):1469-1481. https://doi.org/10. 2138/am-1998-11-1235

Prato FS, Robertson JA, Desjardins D, Hensel J, Thomas AW (2005) Daily repeated magnetic field shielding induces analgesia in CD-1 mice. Bioelectromagnetics 26(2):109 \pm 117 . https://doi.org/10. 1002/bem.20056

Prévot M, Mankinen E, Grommé C, Coe RS (1985) How the geomagnetic field vector reverses polarity. Nature 316:230-234. https://doi.org/10.1038/316230a0

Putman NF, Endres CS, Lohmann CMF, Lohmann KJ (2011) Longitude perception and bicoordinate magnetic maps in sea turtles. Curr Biol 21:463-466. https://doi.org/10.1016/j.cub.2011.01.057

Putman NF, Lohmann KJ, Putman EM, Quinn TP, Klimley AP, Noakes DLG (2013) Evidence for geomagnetic imprinting as a homing mechanism in Pacific salmon. Curr Biol 23:312-316. https://doi. org/10.1016/j.cub.2012.12.041

Putman NF, Jenkins ES, Michielsens CGJ, Noakes DLG (2014a) Geomagnetic imprinting predicts spatio-temporal variation in homing migration of pink and sockeye salmon. J R Soc Interface 11:99. https://doi.org/10.1098/rsif.2014.054 
Putman NF, Scanlan MM, Billman EJ, O’Neil JP, Couture RB, Quinn TP, Lohmann KJ, Noakes DLG (2014b) An inherited magnetic map guides ocean navigation in juvenile Pacific salmon. Curr Biol 24:446-450. https://doi.org/10.1016/j.cub.2014.01.017

Rafinesque CS (1820) Annals of nature or annual synopsis of new genera and species of animals, plants, etc., dis-covered in North America. Thomas Smith, Lexington, KY, USA pp 16

Rao UR (1980) Crucial role of the magnetic field in the evolution of life. Pramana 15(1):33-43

Revell LE, Bodeker GE, Smale D, Lehmann R, Huck PE, Williamson BE, Rozanov E, Struthers H (2012) The effectiveness of $\mathrm{N} 2 \mathrm{O}$ in depleting stratospheric ozone. Geophys Res Lett 39(L15806):1-6. https://doi.org/10.1029/2012GL052143

Ritz T, Adem S, Schulten K (2000) A model for photoreceptor-based magnetoreception in birds. Biophys J 78(2):707-718. https://doi.org/10.1016/S0006-3495(00)76629-X

Ritz T, Dommer DH, Phillips JB (2002) Shedding light on vertebrate magnetoreception. Neuron 34(4):503506. https://doi.org/10.1016/S0896-6273(02)00707-9

Rochalska M (2007) Wpływ pól elektromagnetycznych na organizmy żywe: rośliny, ptaki i zwierzęta. Med Pr 58(1):37-48

Roger J (1861) Die Ponera-artigen Ameisen (Schluss). Berl Entomol Z 5:1-54

Rosenbach FJ (1884) Microorganismen bei den Wund-Infections-Krankheiten des Menschen. J.F. Bergmann, Wiesbaden pp 1-118

Samsonov SN, Manykina VI, Kleimenova NG, Parshina SS, Strekalovskaya AA, Petrova PG (1960) The HELIO-geophysical storminess health effects in the cardio-vascular system of a human in the middle and high latitudes. Wiad Lek, Warsaw, Poland 69(3):537-541

Scanlan MM, Putman N, Putman N, Pollock AM, Noakes D (2018) Magnetic map in nonanadromous Atlantic salmon. PNAS 115(43)201807705. https://doi.org/10.1073/pnas.1807705115

Schleifer KH, Schuler D, Spring S, Weizenegger M, Amann R, Ludwig W, Kohler M (1991) The genus Magnetospirillum gen. nov. description of Magnetospirillum gryphiswaldense sp. nov. and transfer of Aquaspirillum magnetotacticum to Magnetospirillum magnetotacticum comb. nov. Syst Appl Microbiol 14:379-385. https://doi.org/10.1016/S0723-2020(11)80313-9

Schulten K, Swenberg C, Weller AA (1978) biomagnetic sensory mechanism based on magnetic field modulated coherent electron spin motion. Z Phys Chem 111:1-5. https://doi.org/10.1524/zpch.1978. 111.1.001

Schulten K, Windemuth A (1986) Model for a physiological magnetic compass. Biophysical Effects of Steady Magnetic Fields. Springer Proc Phys, Berlin, pp 9-106

Simpson ET, Kasama T, Pósfai M, Buseck PR, Harrison RJ, Dunin-Borkowski RE (2005) Magnetic induction mapping of magnetite chains in magnetotactic bacteria at room temperature and close to the Verwey transition. J Phys Conf 17(1):108. https://ui.adsabs.harvard.edu/link_gateway/2005JPhCS..17.. 108S/ https://doi.org/10.1088/1742-6596/17/1/017

Slaby P, Tomanova K, Vacha M (2013) Cattle on pastures do align along the north-south axis, but the alignment depends on herd density. J Comp Physiol A 199(8):695-701. https://doi.org/10.1007/ s00359-013-0827-5

Sosunov AV, Golubchak BA, Semkin VY, Melnikov AV (1972) Observation of some biological processes in shielded spaces. In: Sanitary Assessment of Magnetic Fields, Academic Press, Moscow, Russia, pp 144-146

Surma SV, Belostotskaya GB, Shchegolev BF, Stefanov VE (2014) Effect of weak static magnetic fields on the development of cultured skeletal muscle cells. Bioelectromagnetics 35:537-546. https://doi.org/ 10.1002/bem. 21876

Svedhem H, Titov D, Taylor F, Witasse O (2007) Venus as a more Earth-like planet. Nature 450:629-632. https://doi.org/10.1038/nature06432

Tarduno JA, Cottrell RD, Watkeys MK, Hofmann A, Doubrovine PV, Mamajek EE, Liu D, Sibeck DG, Neukirch LP, Usui Y (2010) Geodynamo, solar wind, and magnetopause 3.4 to 3.45 billion years ago. Science 327(5970):1238-1240. https://doi.org/10.1126/science.1183445

Teixeira da Silva JA, Dobránszki J (2014) Impact of magnetic water on plant growth. Environ Exp Biol 12(4):137-142

Teixeira da Silva JA, Dobránszki J (2016) Magnetic fields: how is plant growth and development impacted? Protoplasma 253:231-248. https://doi.org/10.1007/s00709-015-0820-7

Tombarkiewicz B (2008) Effect of long-term geomagnetic field deprivation on the concentration of some elements in the hair of laboratory rats. Environ Toxicol Phar 26(1):75-79. https://doi.org/10.1016/j. etap.2008.02.003

Tombarkiewicz B, Pawlak K, Lis M, Niedziółka J (2010) Wpływ zaburzeń pola geomagnetycznego na lokalizację nor i miejsc legowiskowych wybranych gatunków zwierząt wolno żyjących. Acta Sci Pol Zootechnica 9(4):239-250 
Torres de Araujo FF, Pires MA, Frankel RB, Bicudo CE (1986) Magnetite and magnetotaxis in algae. Biophys J 50(2):375-378

Tsetlin VV, Moisa SS, Levinskikh MA, Nefedova EL (2016) Effects of very small doses of ionizing radiation and hypomagnetic field change physiological characteristics of higher plant seeds. Aviakosm Ekolog Med 50(6):51-58. https://doi.org/10.21687/0233-528x-2016-50-6-51-58

Uffen RJ (1963) Influence of the Earth's core on the origin and evolution of life. Nature 198:143-144. https://doi.org/10.1038/198143b0

Vacha M, Drstkova D, Pużova T (2008) Tenebrio beetles use magnetic inclination compass. Naturwissenschaften 95(8):761-765. https://doi.org/10.1007/s00114-008-0377-9

Valkovic VA (1977) A possible mechanism for the influence of geomagnetic field on the evolution of life. Origins Life Evol B 8:7-11. https://doi.org/10.1007/bf00930933

Wajnberg E, Acosta-Avalos D, Alves OC, Fereira de Oliveira J, Srygley RB, Esquivel DM (2010) Magnetoreception in eusocial insects: an update. J Roy Soc Interface 7(2):S207-S225. https://doi.org/10. 1098/rsif.2009.0526.focus

Walbaum JJ (1792) Petri artedi Sueci genera piscium. in Quibus systema totum ichthyologiae proponitur cum classibus, ordinibus, generum characteribus, specierum differentiis, observationibus plurimis. Redactis speciebus 242 ad genera 52. Ichthyologiae. A.F. Rose, Grypeswaldiae [= Greifswald]. No. Pars iii: 1-723, pls. 1-3.

Walker MM, Kirschvink JL, Ahmed G, Dizon A (1992) Evidence that fin whales respond to the geomagnetic field during migration. J Exp Biol 171(1):67-78

Walker MM, Diebel CE, Haugh CV, Pankhurst PN, Montgomery JC, Green CR (1997) Structure and function of the vertebrate magnetic sense. Nature 390(6658):371-376. https://doi.org/10.1038/37057

Walker MM, Dennis TE, Kirschvink JL (2002) The magnetic sense and its use in long-distance navigation by animals. Curr Opin Neurobiol 12(6):735-744. https://doi.org/10.1016/s0959-4388(02)00389-6

Wang X, Liang L (2009) Effects of static magnetic field on magnetosome formation and expression of mamA, mms13, mms6 and magA in Magnetospirillum magneticum AMB-1. Bioelectromagnetics 30(4):313-321. https://doi.org/10.1002/bem.20469

Wang XB, Xu ML, Li B, Li DF, Jiang JC (2003) The taste of one day- old chicks incubated in hypomagnetic field avoids long-term memory impairment. Chin Sci Bull 48:2042-2045

Watanabe S, Yamanak M, Sakai A, Sawada K, Iwasa T (2009) Laser raman spectroscopic study on magnetite formation in magnetotactic bacteria. JILM 73(5):334-339. https://doi.org/10.2320/matertrans. MER2007333

Wei Y, Pu Z, Zong Q, Wan W, Ren Z, Fraenz M, Hong M (2014) Oxygen escape from the Earth during geomagnetic reversals: implications to mass extinction. Earth Planet Sci Lett 394:94-98. https://doi. org/10.1016/j.eps1.2014.03.018

Weldin JC (1927) The colon-typhoid group of bacteria and related forms. Relationships and classification. Iowa State J Sci 1:121-197

Wiltschko R, Wiltschko W (2006) Magnetoreception Bioessays 28(2):157-168. https://doi.org/10.1002/ bies. 20363

Wiltschko W, Merkel FW (1966) Orientierung zugunruhiger Rotkehlchen im statischen Magnetfeld. Verh Deut Z 32:362-367

Wiltschko W, Wiltschko R (1996) Magnetic orientation in birds. J Exp Biol 199(1):29-38. https://doi.org/ 10.1007/978-1-4615-6787-5_2

Wiltschko W, Wiltschko R (2005) Magnetic orientation and magnetoreception in birds and other animals. J Comp Physiol 191(8):675-693. https://doi.org/10.1007/s00359-005-0627-7

Xiao Y, Wang Q, Xu ML, Jiang JC, Li B (2009) Chicks incubated in hypomagnetic field need more exogenous noradrenaline for memory consolidation. Adv Space Res 44:226-232. https://doi.org/10.1016/j. asr.2009.04.013

Yan L, Zhang S, Chen P, Liu H, Yin H, Li H (2012) Magnetotactic bacteria, magnetosomes and their application. Microbiol Res 167(9):507-519. https://doi.org/10.1016/j.micres.2012.04.002

Yang SY, Chiu MJ, Chen TF, Horng HE (2017) Detection of plasma biomarkers using immunomagnetic reduction: A promising method for the early diagnosis of Alzheimer's disease. Neurol Ther 6(1):3756. https://doi.org/10.1007/s40120-017-0075-7

Yosef R, Raz M, Ben-Baruch N, Shmueli L, Kosicki JZ, Fratczak M, Tryjanowski P (2020) Directional preferences of dogs' changes in the presence of a bar magnet: Educational experiments in Israel. J Vet Behav 35:34-37. https://doi.org/10.1016/j.jveb.2019.10.003

Zaguła G, Puchalski C, Gorzelany J (2011) Spektrofotometryczna metoda oceny wpływu pól magnetycznych stałych i wolnozmiennych stosowanych w czasie wzrostu i dojrzewania, na równowagę glukozowo-fruktozową wybranych odmian jabłek. Inż Roln A 9(134):269-277 
Zhang B, Lu H, Xi W, Zhou X, Xu S, Zhang K, Jiang J, Li Y, Guo A (2004) Exposure to hypomagnetic field space for multiple generations causes amnesia in Drosophila melanogaster. Neurosci Lett 371:190195. https://doi.org/10.1016/j.neulet.2004.08.072

Zhang J, Ding C, Ren L, Zhou Y, Shang P (2014) The effects of static magnetic fields on bone. Prog Biophys Mol Biol 114:146-152. https://doi.org/10.1016/j.pbiomolbio.2014.02.001

Zhang J, Ding C, Meng X, Shang P (2017) Nitric oxide modulates the responses of osteoclast formation to static magnetic fields. Electromagn Biol Med 37(1):1-12. https://doi.org/10.1080/15368378.2017. 1414057

Zhang Y, Berman GP, Kais S (2015) The radical pair mechanism and the avian chemical compass: quantum coherence and entanglement. Int J Quant Chem 115(9):1327-1341. https://doi.org/10.1002/qua.24943

Zuluaga JI, Bustamante S (2018) Geomagnetic properties of Proxima Centauri b analogues. Planet Space Sci 152:55-67. https://doi.org/10.1016/j.pss.2018.01.006

Publisher's Note Springer Nature remains neutral with regard to jurisdictional claims in published maps and institutional affiliations. 